\title{
Curiosity, youth, and knowledge in the visual and textual culture of the Dutch Republic
}

\author{
Els Stronks (iD) \\ Utrecht University \\ E-mail: E.Stronks@uu.nl
}

\begin{abstract}
Argument
The imitation of adults was the dominant educational early modern model, as it had been from the classical era. Yet, from 1500 onward, this traditional model clashed with new pedagogical ideals that explored if and how the youthful mind differed from the adult. To investigate this clash, I examine individual and aggregate cases - taken from the Dutch (illustrated) textual culture - representing conceptualizations of what has been labelled "the curiosity family" (concepts such as curiosity, inquisitiveness, invention). As previously established, during the seventeenth century, curiosity turned from a vice to a virtue among adults. Textual evidence suggests that for the early modern Dutch youth, docility, long valued, remained the guiding ideal. Shortly after 1700, however, two changes can be detected: for youth, travel literature and travel as a metaphor became a means to explore the world without adults; and for adults, the experimental learning style of the young became a new learning model.
\end{abstract}

Keywords Early modern knowledge culture; youth

\section{Introduction}

In this paper, I investigate how the concept of youthful curiosity was articulated and represented in the textual and visual culture of the Dutch Republic in the early modern period. Between the sixteenth and eighteenth centuries, curiosity as a knowledge category was defined by a wide range of qualifications, varying from negative evaluations such as "devastating to mankind" to positive ones such as "commendable." Words used to describe the concept curiosity thus vary from "useless" and "vain" to "valuable" and "indispensable." A number of scholars have identified a re-appreciation of the quality "curiosity" during the late seventeenth century, and have labelled the turn toward a more positive evaluation as the driving force behind the transition to a more empirically based knowledge culture in sixteenth-, seventeenth- and eighteenth-century Europe (recently, for instance, Cohen 2010; Huff 2011). Cultural historians have, for instance, studied the growing interest in objects of inquiries to argue that the cultural practices associated with these objects (exhibitions, exotic collections, "curiosity cabinets," etc.) indicate the development of a new knowledge culture (see, for instance, Evans and Marr 2004). In the existing studies, "age" is an understudied aspect, in the sense that it is often tacitly implied that curiosity became a virtue related and relevant solely to adults. How the curiosity of early modern children and adolescents was represented and perceived, and how this type of framing fed into the transition to a new knowledge culture, is an open and important question.

I will address this question by exploring representations of youthful curiosity in (illustrated) texts published in the Dutch Republic, using digital techniques and linguistic analysis. The scholar of literature Barbara Benedict has remarked on the new status that curiosity gained in texts for adults during the late seventeenth century. She noticed the growing interest in texts with descriptions of monsters, rare collections, and museums that contained and disseminated contemporary attitudes toward curiosity. In her words, curiosity entailed "the subversiveness of asking and the 
lawlessness of the intellectual ambition to know more" (Benedict 2001, 245). She argues that the new appreciation of curiosity sparked a spirit of inquiry that slowly replaced the principle of submission to classical and biblical authorities. The concept "curiosity" underwent a major change, Benedict claims, in literary representations that engaged people (including scientists, authors, performers) in practicing and producing new forms of curiosity (ibid., 1).

The new forms entailed much more positive interpretations of the concept curiosity. From the patristic period up to the late seventeenth century, curiosity was not regarded as a virtue, but as an intellectual vice (Newhauser 2013). In those centuries, in their reading of the Genesis narrative, Europeans attributed the fall of mankind to the desire for knowledge. The production of predominantly negative cultural representations of the concept curiosity up to the late seventeenth century were rooted in this reading of Genesis. This view, for example, the popular Dutch poet Jacob Cats expressed in his meditative poem Self-Stryt dating from 1620: "You know, or should know, that the first woman ever born, Eve, once gave into to her curious eye; and this curiosity caused Adam and Eve to be expelled and brought death to all of us, their descendants." ${ }^{1}$

Like many others at the time, Cats associates this vice with Eve; he links curiosity with Eve and because of that association, curiosity becomes a vice. Many existing studies do have an eye for the gender bound nature of many of the discourses on curiosity. Benedict for instance maintains that Eve is perceived as "the Christian mother of evil" (Benedict 2001, 122). During the seventeenth century, Benedict further argues, cultural representations of curiosity as negative were slowly replaced by (often illustrated) texts that channeled and enabled empirical explorations. Rather than lament the Fall itself, these newly developed (illustrated) texts exhorted their viewers and readers to explore the world that resulted from the Fall.

In French and German early modern textual cultures, Neil Kenny noticed the same change in the valuation of curiosity. In The Uses of Curiosity in Early Modern France and Germany, he discusses how universities, churches, and other institutions thematized curiosity through language in order to regulate knowledge and behavior. Kenny contends that curiosity became a fashionable topic in discourses of many communities. Early modern German and French conduct manuals, university dissertations, scientific treatises, sermons, newspapers, novellas, plays, operas, ballets and poems published between the sixteenth and the eighteenth centuries all show a growing interest in the nature and empowering force of curiosity (Kenny 2004).

Kenny's focus on universities as one of the institutions that possessed vocabularies for the category of curiosity, implies an interest in the young - but only young adults well beyond their childhood years. The question if and how curiosity was related to early modern youth (children and adolescents, loosely defined here [for the Dutch context] as "the unmarried" [Dorren 2001, 40]) has rarely been approached from a cultural perspective. ${ }^{2}$ That is to say, only sixteenth and eighteenth century developments have been included in the study of the early stages of the conceptualization of childhood as a social construct that occurred after the publication of Philippe Ariès's L'Enfant et la vie familiale sous l'Ancien Régime in 1960 (for an overview see, for example, Frijhoff 2012, and for the Dutch context Koops 2001 and Koops 2016).

Research on the history of the education of children has made apparent that the imitation of adults that was the dominant early modern educational model, as it had been from the classical era, clashed with new pedagogical ideals that explored if and how the youthful mind differed from the adult. Debates about the role of youthful curiosity were at the heart of these clashes, and especially the sixteenth and eighteenth-century extremes of these clashes have been noticed. It was Augustine who had placed discovery-based learning, driven by a pupil's curiosity, at the center of pedagogical debates in the fourth century when he asserted that the true art of teaching was to

\footnotetext{
${ }^{1}$ The original Dutch quotation: “Ghy weet, of weetjet niet, ghy dientet wel te weten,/Dat Eva, 't eerste wijf, haer eerstmael heeft vergeten/Door haer nieusgierigh oogh; dat heeftse wegh geruckt,'/En ons, haer deerlijck zaet, tot in de doot gedruckt” (Cats 1862, 261).

${ }^{2}$ Absent, for instance, in Müller 2006 and Müller 2009.
} 
stimulate a learner's curiosity, even as he emphasized the dangers of the desire to obtain knowledge (Jacobs 2005). Augustine's negative views of curiosity dominated amongst humanists. See, for instance, Desiderius Erasmus, De pueris instituendis, on a liberal education for children (1529) and reformers such as Luther who based their pedagogical ideas on the Genesis narrative and thus on the assumption that children and adolescents were sinful at birth and in need of correction. Reformers pursued the correction of sinning nature through practices of memorization and repetition of existing dogma and bodies of knowledge. Erasmus and Montaigne acknowledged the opportunities of education and of self-corrective behavior, focusing on the question of how to get young people to the point that they think for themselves and make wise decisions, but they did not encourage unbridled curiosity (Strauss 1978; Walsham 2011). During the eighteenth century, the negative valuation of curiosity was slowly replaced by Locke's conception of children as tabula rasa and Rousseau's idea of children as uncorrupted beings of nature. Both Locke and Rousseau took as their starting point children's capacity to improve, rather than youthful sinfulness (Cunningham 2014). Rousseau, in particular, contended that a child's learning should be explorative: not parrot-like, but like a cat's exploration - based on an instinctive desire to know the environment (Houswitschka 2006, 84).

From existing research, we know that specific segments of these textual cultures (namely children's books and textbooks) in the course of the eighteenth century slowly developed into guides that actively promoted curiosity and inquisitiveness amongst children. With regards to children's books, for instance, the main character of The Family Instructor (1715), an educational treatise by Defoe - the author of Robinson Crusoe (1719), that started out as an adult novel but metamorphosed into one of the most successful children's novels ever - is a young boy who excels in asking his parents every possible question. Similar trends have been observed in children's literature more generally (Jochum 2006, esp. 157-159). In the Spectacle de la nature (first volume published in 1732), the abbé Noël-Antoine Pluche advocated the study of nature to excite the curiosity of children; he also advised that curiosity be "exercised with precaution and holding back" (Koepp 2006; quoted from Blair 2016, 93). Penny Brown has highlighted how French children's books used dialogue to engage and stimulate young female readers. In Mme Le Prince de Beaumont's work, Les Conversations d'Emilie (1773), the main character Emilie is depicted as "bright and chirpy, self-confident and often funny, endlessly curious and of course eager to learn" (Brown 2009, 212). Emilie's curiosity becomes obvious in the long dialogues she has with adults who applaud her curious behavior and in doing so send a strong message to the young readers. Nina Christensen describes how fictive letters in eighteenth-century Danish novels for children also served to spark curiosity, as becomes apparent from prefaces in which authors declare that they expected their young audience to be naturally curious about the topics they chose to address in these letters (Christensen 2009, 191).

The appreciation of youthful curiosity appears to have continued to grow. Nowadays in Western societies, curiosity is often represented as a naturally and even restrictedly youthful characteristic. Philosopher Susan Neiman recently argued in Why Grow Up? that during the Enlightenment, Kant and Rousseau made the life cycle of individuals a focal point of Western philosophy, resulting in the modern idea that the best time of one's life is the decade between sixteen and twenty-six (Neiman 2014; see Fornäs 1995 for an overview). This idea, as Robert Pogue Harrison observed in Juvenescence: A Cultural History of Our Age, has generated a collective drive to make oneself younger in looks, behavior, mentality and lifestyle. Harrison lists curiosity as one of the typical psychic modes ascribed to the young to which all generations aspire (Harrison 2014, 39-40).

In the early modern era, literacy rates and the percentages of the young population with primary and secondary education were relatively high in the Netherlands, especially in the Dutch Republic, in comparison to other European countries (see for instance Frijhoff and Spies 2004, 236-257; Houston 2002, 108). The growing literacy of this population group and their increasing dependency on knowledge transmission over the course of the eighteenth century, not only through children's books but also text books and publications, has been firmly established (for 
children's books, see Salman 2001; for a bibliography of text books, see Buijnsters and BuijnstersDe Smet 1999; and for developments within a specific text book genre, see Buijnsters 1995). From 1780 onward, Dutch intellectuals (lawyers, professors, and physicians) introduced an innovation in the Dutch educational system. Their aim was to design a more inclusive system, accessible not only to the country's intellectual elite but also to the less well-to do. They were involved, for instance, in the foundation of the Maatschappij tot Nut van 't Algemeen [Society for Public Welfare], a non-profit organization for the purpose of developing individuals and society primarily through education, in 1784, which set out to publish lower cost text books. Public education improved through the intellectuals' efforts, resulting for instance in a new educational law launched in 1806 that required teachers to be properly educated (Lenders 1988). The changes in the (late) eighteenth century have been studied and charted. The current state of research however prompts the question: what views on youthful curiosity existed during the second half of the seventeenth century in early modern literate communities, when the transition to a more positive appreciation of curiosity was made in the adult world? I will investigate cases taken from the Dutch textual culture that represent conceptualizations of what has been labelled "the curiosity family" (curiosity, and for instance also inquisitiveness and invention), but I will also set up another line of inquiry into representations of children's learning styles. Both forms of representation will allow for insights in the way the concept of youthful curiosity was articulated and perceived.

There is strong evidence that these cultural representations of curiosity - especially textual and visual representations in printed forms - impacted not only the life of adults, but also the early modern youth. In the Dutch Republic, in particular, with its enormous printing industry and high level of literacy, textual representations of curiosity formed the focal point of early modern debates on youth, which circled around the question whether young people were to be depicted as a population group whose inquisitive nature needed to be controlled and constrained, or as a population group with cognitive potential and capacities for innovation (Stronks 2015). As youth was actively involved in this rich array of discrete textual cultures, the Dutch youth may well have gained knowledge about themselves and their identity as youth through representations of them as found in songs, poetry, plays, treatises, sermons, pamphlets, etc. Texts about and for the youth were often known to both the adults and young people: in the case of luxurious song books for young adults for instance because the parents selected and purchased these items (Grootes 1987). This indicates a wide dissemination of the ideas given in textual and visual representations, and thus in theory a good breeding ground for societal debates and development of ideas and concepts.

\section{Charting the "Curiosity Family" Digitally}

How to inspect this breeding ground? In The Uses of Curiosity in Early Modern France and Germany, Kenny establishes the presence of a "curiosity family." He indicates the instability of curiosity as both a concept and a set of words, as well as the fuzzy boundaries of its semantic and conceptual borders that make the study of curiosity inherently problematic (see also Evans and Marr 2004, 2). By charting the semantic web surrounding the word "curiosity," he inventories a great number of terms authors used and invented in order "to shape and reshape the thing or things that they considered curiosity to be" (Kenny 2004, 8). Specific members of this family, including the term curiosity itself, carried distinct and sometimes even in themselves contradictory meanings, some of them not very positive at all (ibid., 3 ). Since "curiosity" in the early modern period signified a number of very different things in different contexts, Kenny assumes no conceptual core but rather a (growing, changing?) semantic field. Due to its unstable nature, the concept "curiosity" could well be qualified as a so-called "contested concept." Within every human language, concepts are developed and used to understand the world. According to Gallie (Gallie 1956) some of those concepts are essentially questionable and corrigible, and permanently subject to revision even though there may be an "exemplar use" on which various parties, for practical reasons, agree. These complex, contested concepts evoke endless discourses that are 
especially hard to chart because of the various understandings and articulations of the concept that might exist at the same time. The ramifications of Gallie's terminology and ways to conduct research into contested concepts have been heavily debated (see Collier et al. 2006 for an overview).

Scholars have typically approached the study of these concepts and their inherent historicity - each era has its own controversies - through time-intensive, traditional close reading of a limited number of texts that serve as a recording of historical discourses (see, for instance, Koselleck 2006). Digital analysis and distant reading now offer a complementary approach (e.g. Van Eijnatten et al. 2014). The current wealth of digital textual and lexicographical data and the state of the art in natural language processing techniques provide a promising and challenging basis to study concepts over time. Although the potential of these data and techniques is not yet fully realized, resulting in limited utility of these tools for such a complex task, I will nonetheless use digital means to obtain an overview as well as an in-depth look on conceptual shifts and developments. In an attempt to trace these shifts, I will chart the uses of a great number of words related to curiosity (Kenny 2004, 13).

This approach casts a wide net. It cannot, however, encompass all feelings, attitudes, and thoughts related to terms of the "curiosity family," as is demonstrated by looking at the randomly chosen case of the four-language dictionary Dictionarium Tetraglotton, published in 1562 by the Antwerp publisher Christoffel Plantin. In his preface, Plantin dedicated this dictionary to the Dutch ("Belgica") youth when he explains to have published the book "ut totius Galliae Belgicae pubes commune habeat vernaculo idiomate Dictionarium" (Plantin 1562, preface, unnumbered folio). He was perhaps inspired by Robert Estienne's Dictionariolum puerorum, published in 1542 (De Neve 1963, 201). The publication is clearly meant to build upon existing interest in the Flemish youth and meant to spark youthful interest and enthusiasm for lexicology and philology and thus for lexical inquiry. We find, however, no mention of any word related to inquiry, inquisitiveness, or curiosity in Plantin's preface to the volume (Langereis 2014). At best, Plantin uses a word like "studium." The case of the Dictionarium Tetraglotton not only shows the limitation of a lexical approach in conceptual research, but also shows that a cultural inquiry into the role of representations of the curiosity family in the Low Countries is ideally not restricted to the Dutch language, but also includes texts in French, Latin, and perhaps even Greek.

Methodologically speaking, it would also be ideal to study at least a representative, if not complete, textual data set to perform a large-scale analysis of trends and topics in early modern Dutch textual culture. Such a data set is at present not available, but existing digital infrastructures do offer the opportunity to look at word frequencies in the corpus of Dutch texts printed between 1600-1800 - that is to say, only in the part of that corpus that has been digitized by the Digital Library of Dutch Literature (DBNL) and antecedents the existing nGram tool (fig. 1). ${ }^{3}$

Acknowledging all these constraints, an intriguing feature of the textual vernacular culture of the Low Countries is revealed by the nGram viewer. All most obvious words - Dutch members of the "curiosity family" - have been included in this chart of word frequencies: nieuwsgierig, nieuwsgierigheid, curieus, curieusheid, neuswijs, neuswijsheid, weetgierig, weetgierigheid, weetzuchtig, weetzuchtigheid, leergierig, leergierigheid, leerzaam, leerzaamheid, weetgraag, weetlust:

A number of conclusions can be drawn from the overview presented by this graph. Massive discussions using words from the "curiosity family" only appear to be thriving around and after 1700. This graph visualized absolute frequencies: each line represents the frequency of one specific search term entered in the nGram. In total, the graph thus shows that the concept "curiosity" was

\footnotetext{
${ }^{3}$ http://www.kbresearch.nl/dbnl/ngram-viewer/. The DBNL holds only a portion of all published Dutch texts from the early modern period, but given the volume of texts that have been digitized ( 4 million pages) and the careful selection of the digitized sources we these results have some relevance. This selection is, however, the result of different, and in themselves rational decisions to digitize important texts, like newspapers. Even with the strategic data production of underrepresented textual resources, coverage will always be partial and incomplete in nature (for instance: some concepts made it into written texts less often than others; some texts are lost over time, especially so in earlier ages). Additionally, analytical tools can never produce objective results; they are always subject to interpretation. With special thanks to $\mathrm{PhD}$ student Cora van de Poppe who conducted this part of the research with me.
} 


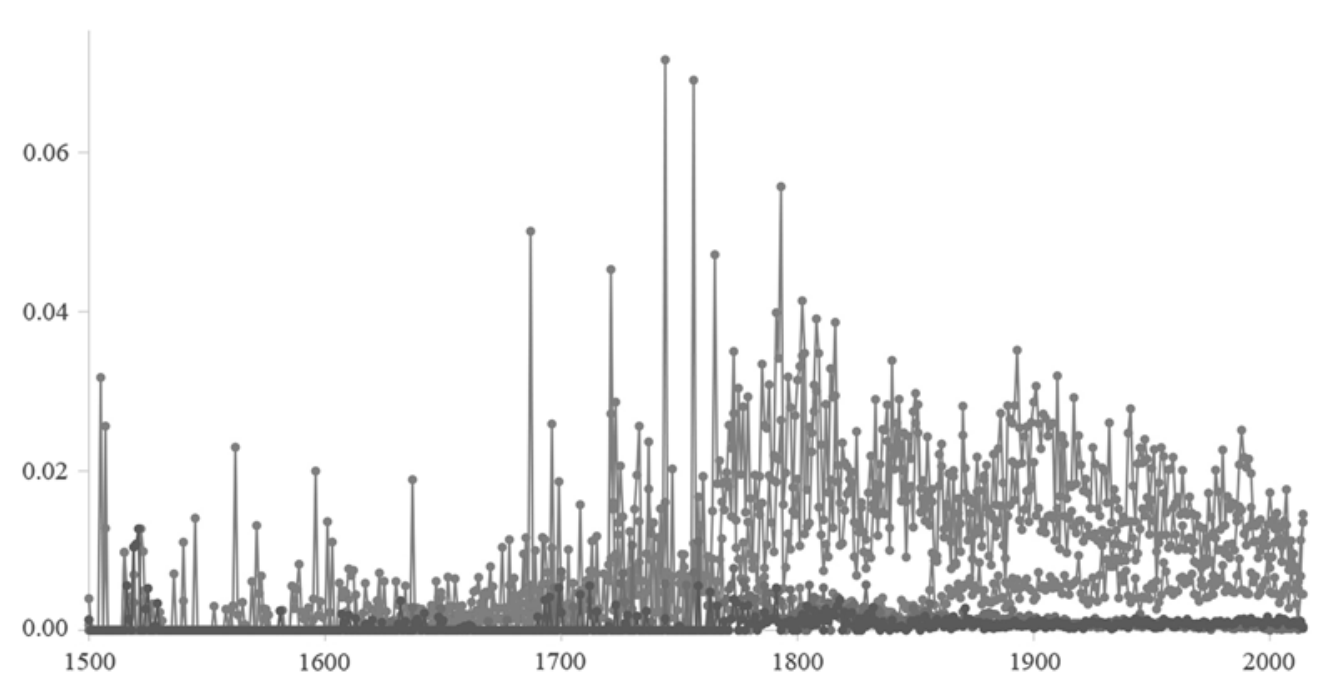

\section{Ngram instellingen}

nieuwsgierig
$(28182)$
nieuwsgierigheid
$(20600)$
curieus (8034)
weetgierig (1463)
leergierig (1462)

met spellingsvarianten:

nieu-schier, nieusgier, nieus-gier, nieusgiere, nieusgierig, nieus-gierig, nieusgierigh, nieus- $\quad$ alle gierigh, nieuwsgier, nieuwsgierig, nieuwsgierige, nieuwsgierigen, nieuwsgierigh, nieuws- genres gierigh, nieuws-gierighe

met spellingsvarianten:

nieusgiericheyt, nieusgierigheit, nieusgierigheyt, nieuwsgiericheijt, nieuwsgierigheid, nieuwsgierigheyt

alle genres

met spellingsvarianten:

curieus, curieuse, curieuste, kerjeus, kerjeust, kurieus, kurieuse, kuureieus

alle

genres

met spellingsvarianten:

weetgierig, weetgierige, weetgierigen, weet-gierigen, weet-gierigh, wete-gierigh

alle

genres

met spellingsvarianten:

leergierig, leergierige, leergierigh

alle

genres

Figure 1. Overview produced by the DBNL nGram tool of the frequency and distribution of Dutch words associated with curiosity.

not a particular heavily debated topic in vernacular texts printed in the Low Countries 1600-1700. The peak in the use of words from the curiosity family is situated after 1700 . At the time a number of scholars of the Low Countries were frontrunners in the transition process taking place in the sciences (see for instance Jorink 1999, 7), the transformation of the knowledge culture does not appear to have been one of the trending topics in the Low Countries' textual vernacular culture.

On closer inspection of this use of specific words within the curiosity family (so inspections of all the dots that make up this graph), it becomes apparent that one particular branch of the curiosity family - the words leergierig, leergierigheid, leerzaam, leerzaamheid (inquisitive, inquisitiveness) - was consistently related to youth in texts dedicated to, or printed for youth. A youth specific vocabulary, centered around the notion of "inquisitiveness" was developing, which indicates that the view of youthful curiosity differed from that of curiosity for adults.

A glance at the lemmata from the "curiosity family" in the Dutch translation of Cesare Ripa's authoritative Iconologia gives us a sense of to what effect members of this family were often 


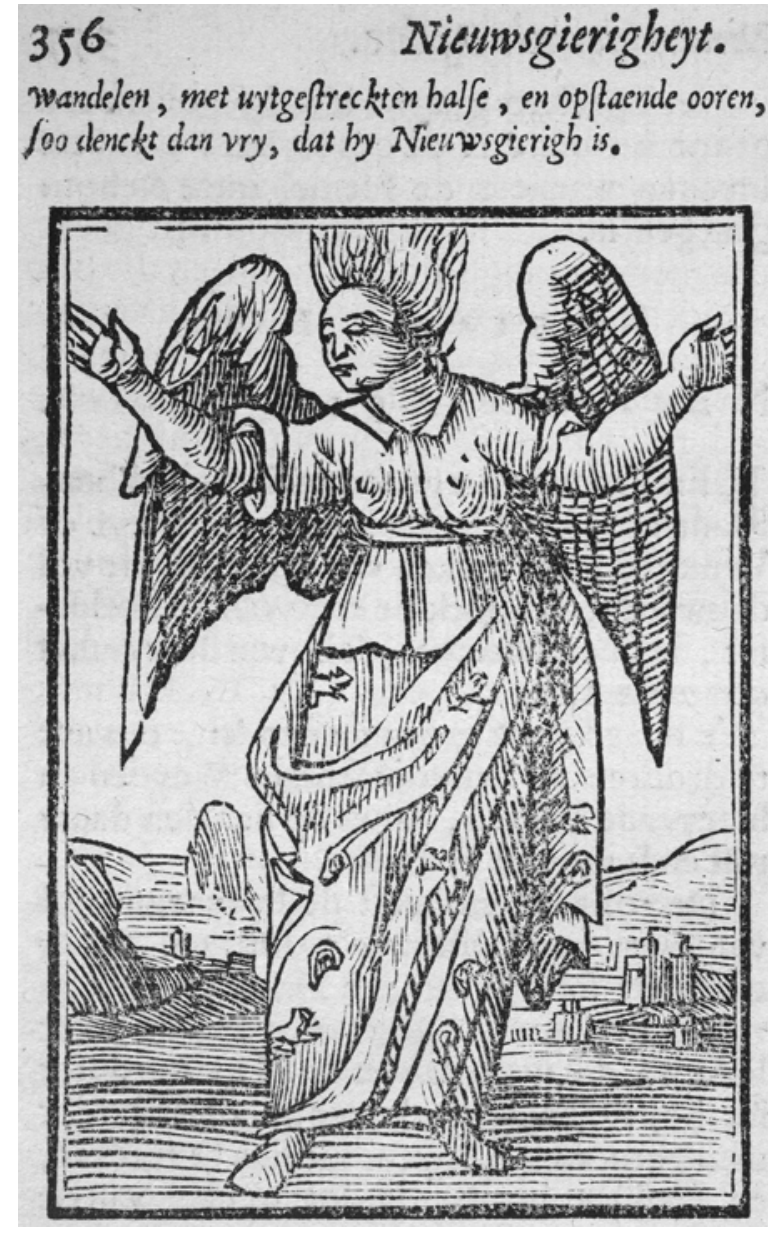

Figure 2. Cesare Ripa's Iconologia of Uytbeeldinghen des Verstants, vertaald door Dirck Pietersz. Pers [Cesare Ripa's Iconologia or depiction of wisdom, translated by Dirck Pietersz. Pers], Amsterdam 1644. Met introductie van Jochen Becker, Davaco Publishers, Soest 1971, 355. (c) Royal Library, The Hague.

associated with youth in the Dutch context. Ripa's anthology of metaphors and personifications was first printed in 1593, in Italian. It was then translated into other European languages, changing slightly or drastically with each translation. In the first illustrated Italian version dating from 1603 , no picture of curiosity was included, but the personification of curiosity is described as a woman with the habit of browsing into other people's affairs: "A woman in a red and blue garment, covered with lots of ears. Her rough hair loaded with frogs, her hands raised in the air. Her head is bending forward and she carries wings."4 In the first Dutch translation by Dirck Pietersz. Pers, dating from 1644, conveyed a similarly negative image of curiosity, and provided a woodcut that matches the description of the Italian edition of 1603: "Curiosity is the unbridled desire of those who want to know more than they should." 5

As the picture (fig. 2) shows, curiosity is female - like Eve - but not particularly young. The related lemma "Docilitate" (not found in the 1603 Italian edition, but present for instance in the Italian edition of 1625 [Ripa 1625, 186]) in the Dutch edition contains references to both the

\footnotetext{
${ }^{4}$ Original quotation in Italian: “Donna con vestimento rosso, \& azurro, sopr'il quale vi siano sparse molt'orecchie, \& rane havere à i capelli dritti, con le mani alte, col capo che sporga in fuora, \& sarà alata” (Ripa 1603, 99). Translation provided by Philiep Bossier.

${ }^{5}$ Original Dutch quotation: 'Nieuwsgierigheyt is een ongetoomde begeerlijckheyt in die geene, die meer soecken te weeten als haer wel betaemt' (Ripa 1971 [1644], 355).
} 
parrot as mirrors as symbols of the capacity to mimic. In this particular lemma, a connection with youth is made. "Docilitate" is represented by a "Een Iongh Maegdeken" [ a young virgin], dressed in white, with her arms wide open just like "Curiosity": "She carries a mirror on her chest to show that students should, just like a mirror, mimic everything presented to them."

The mind of the youngster is thus associated with docility and the abilities to mimic. These abilities appear to set the mind of the young apart from that of the adults, but because it is the ability to mimic those adults, the difference was not perceived as fundamental. The young mind only differed in its ability to absorb the example set by the adult. It was the adult's example, however, that it absorbed. In the end, the mind of the young appears to have been perceived as an immature version of the adult mind it was supposed to copy.

The oldest reference to leergierige jeugd is found in Den Nederduytschen Helicon (1610), written by a group of rhetoricians from Haarlem and Leiden. The preface to the Constlievende Jeught [Art Loving Youth] opens with an invitation to Dutch youth to explore the Den Nederduytschen Helicon that derived its title from the Greek mountain Helicon, the classical source of poetic inspiration: "Come, if you want to know more about Phoebus, feel free to enter this Helicon, its beautiful home."7 The word leergier (inquisitiveness) has a positive connotation here: the poem is an invitation for the youth to take part in the literary, learned, and adult culture as represented by the volume Den Nederduytschen Helicon.

Another poem in this volume addresses the curiosity of Dutch youth in an equally positive manner and is even more explicit about the relationship among youth, curiosity, and literature. In Choor, ofte, Versamelinghe des Muses [Choir, of Gathering of the Muses], young people are urged to imprint everything they read onto their minds: "Oh, poetry-loving youth, be aware and do as is on display here, in this volume: imprint that which constitutes the arts in your mind."

Reading without taking enough time to let impressions sink in is to be avoided: want Wetenschap is al vervloghen [knowledge slips away] when one reads without proper concentration and care (Den Nederduytschen Helicon 1610,60). Young people should read with the purpose of producing their own stichtbaer werc [edifying books] in honor of their country (Den Nederduytschen Helicon 1610, 60-61).

Not only in the Den Nederduytschen Helicon, but also in many seventeenth- and eighteenth-century Dutch texts, youthful inquisitiveness is connected to the advice to gain knowledge by reading books (e.g., Feike Dietz, in this volume on literary techniques that were used to transfer this knowledge to young readers). This connection is underpinned and enforced by Dutch editions of Ripa's Iconologia that - from the middle of the seventeenth century onwards - were almost all directed towards young audiences (Zimmermann 1995, 22). Shown in fig. 3 is an early eighteenth-century copper engraving found in Houbraken's Stichtelyke zinnebeelden [Edifying Emblems] (Houbraken 1767, fol. 2r):

Inquisitiveness is a positive feature, as the accompanying poem explains, if it is based on the reading of Latin and Greek books. The young girl has a swine as an attribute (to demonstrate that Inquisitiveness despites ignorance) and a mirror (showing her capability to mimic). The ideal behind it appears to be that of reproducing the knowledge found in books.

In another instance, in J.P. Broeckhoff's Dichten zedekundige zinnebeelden en bespiegelingen, youth is presented, on the title page, catching Truth by in the heavenly light with a mirror. Poetry is helping her to catch this light, and young people are urged to follow Poetry's lead (see figs. 4 and 5), while the busy youth collects books by poets, masters of iconography. ${ }^{9}$

\footnotetext{
${ }^{6}$ The original Dutch quotation: 'De Spiegel draeghtse voor de borst, om dat, gelijck de Spiegel alle gedaenten aenneemt die haer worden vertoont, alsoo neemt de leerlingh de beeldenis van alle dingen aen.' (Ripa 1971 [1644], 355).

${ }^{7}$ The original Dutch quotation: 'Comt Phoebi leergier Jeught, verneert u vry te gaen/Tot desen Helicon, verciert met schoone woningh.' (Den Nederduytschen Helicon 1610, 7).

${ }^{8}$ The original Dutch quotation: 'O Dicht-Jeught dan, weest doch voor sulcks dy wachtigh:/Maer g'lijck hier in dy is gheleert, zijt trachtig,/Om Konsten grondt te drucken in 't gehedacht.' (Den Nederduytschen Helicon 1610, 61).

${ }^{9}$ Dutch quotation: “Terwyl de nyvre JEUGD de Boeken saam vergaart/Van Dichtren, in de Kunst der Beeldenspraak vermaard" (Broeckhoff 1770 , fol. ${ }^{\star} 1 \mathrm{v}$ ).
} 


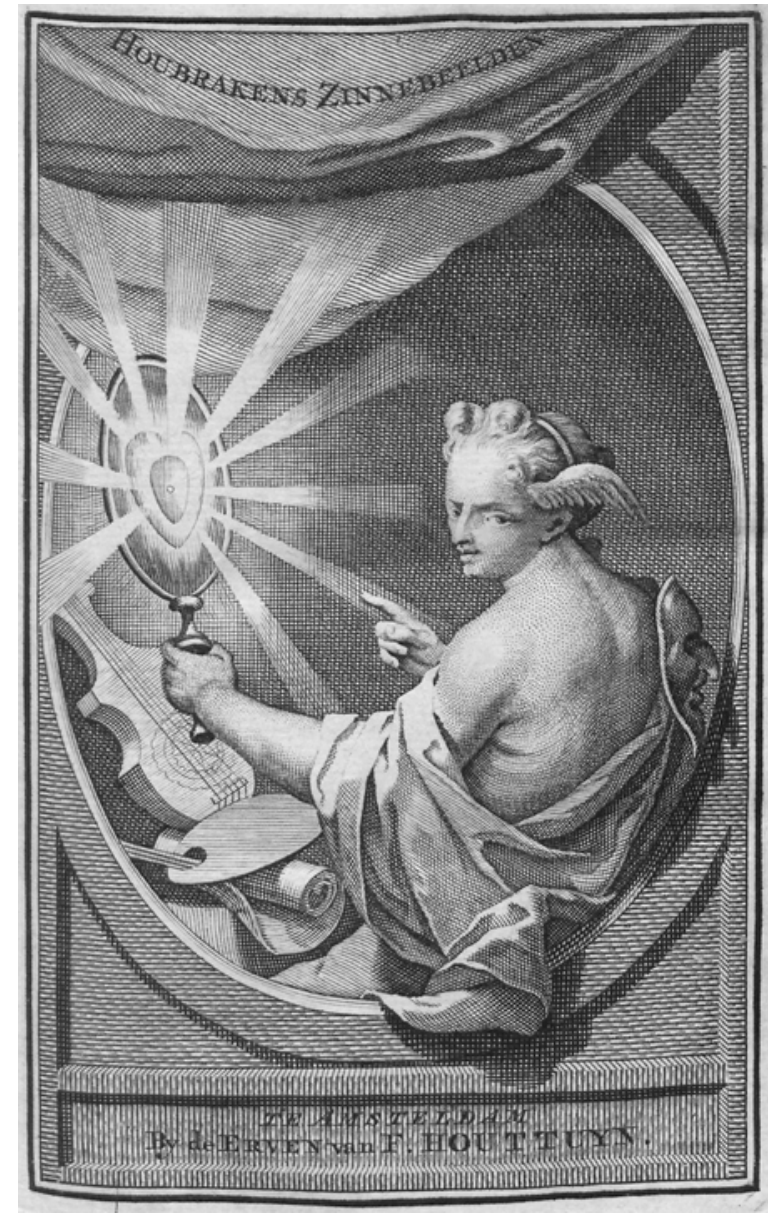

Figure 3. Leersucht [Inquisitiviness] depicted as a young girl, in A. Houbraken, Stichtelyke zinnebeelden, gepast op deugden en ondeugden, in LVII tafereelen vertoond door A. Houbraken, en verrykt met de bygedichten van Juffrouw Gezine Brit [Edifying emblems, applied to virtues and vices, depicted in 57 images made by A. Houbraken and Enriched with poems by Miss Gezine Brit]. Amsterdam 1767. [first edition 1723], fol. 2r. (c) Utrecht University Library.

On pages 129-136, the virtue of "Inquisitiveness" is discussed. Again, the young reader is urged to read and gather information from renown books (see fig. 6). Knowing is paired with believing and acting according to one's faith and Christian values:

Whoever pairs virtue with knowledge, and honours virtue with knowledge, will be blessed and secure. Flowers of Spring, happy youth that will bring us fortune, do pair inquisitiveness with virtue, and knowing to contemplating. ${ }^{10}$

The adult's perspective is also included in this exhortation for young people, as testified by this wishful thinking: "happy youth that will bring us fortune." The virtue of inquisitiveness is obviously also of great benefit to the adults, not just to the young.

Even in an 1801 drawing, we see a man holding up a sign with the words "Allegory of Inquisitiveness" for a group of children, in front of which was believed to be the Dutch founder of the printing press, Laurens Jansz Coster. ${ }^{11}$ From this evidence, we can conclude that in Dutch textual culture, "Inquisitiveness," youth, and "knowledge from books" proved to be a powerful and

\footnotetext{
${ }^{10}$ Dutch quotation: 'Hij die Deugd op Kennis bouwt,/En aan Deugd de Kennis heiligt:/Leeft gezegend en beveiligd./ Lentebloemen, fiere Jeugd,/Telgen daar we vrugt van wachten,/Paart dan LEERZAAMHEID aan Deugd,/En het weeten aan het betrachten.' (Broeckhoff 1770, 136).

${ }^{11}$ Allegorie van de leerzaamheid, 1801. RKD, BD/0180.
} 
Figure 4. Title page, J.P. Broeckhoff, Dicht- en zedekundige zinnebeelden en bespiegelingen [Poetic and edifying emblems and contemplations]. Amsterdam, P.J. Entrop bookseller, 1770, fol. *1r. (c) Utrecht University Library.

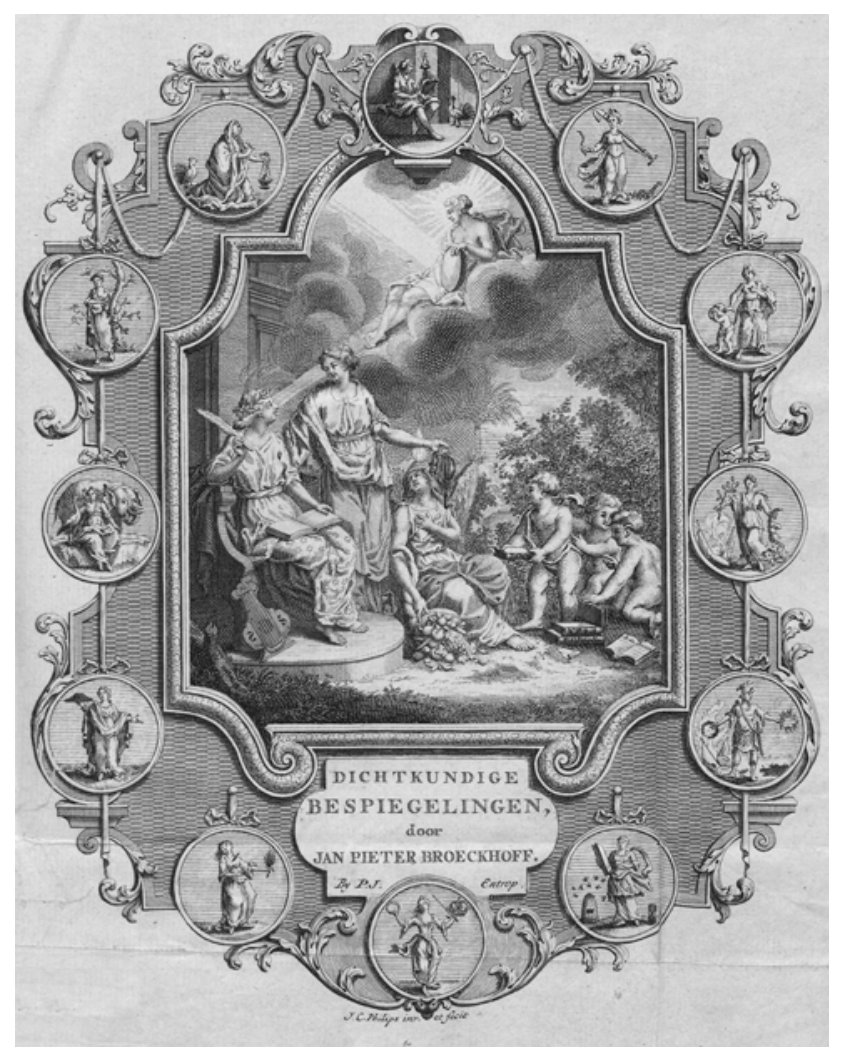

Figure 5. Detail of title page J.P. Broeckhoff, Dicht- en zedekundige zinnebeelden en bespiegelingen [Poetic and edifying emblems and contemplations]. Amsterdam, P.J. Entrop bookseller, 1770, fol. *1r. (C) Utrecht University Library.

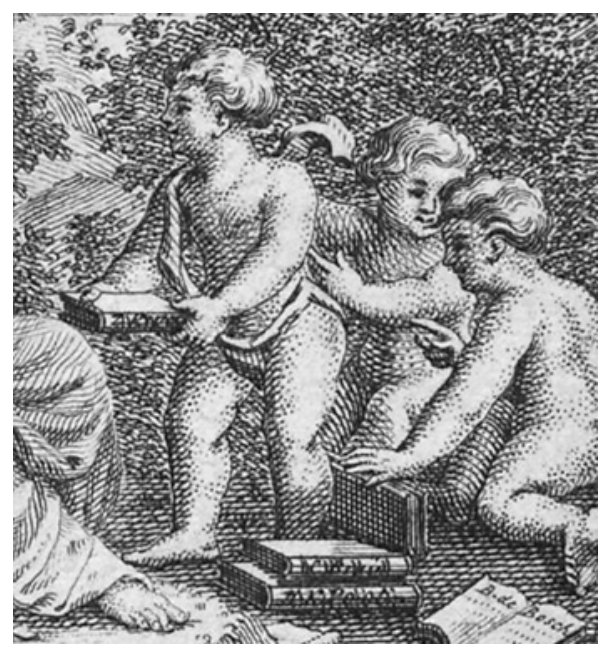

long-lasting combination. It also makes apparent that youthful explorative behavior was restricted to reading along the lines of books written by adults. Gaining knowledge rather than gaining experience was the main message of these representations of the "curiosity family."

A counter-argument against this conclusion appears to be provided by the Dutch adaptation of Ripa's lemma "Inventione." The 1603 Italian version of Ripa includes the lemma "Inventione," but 


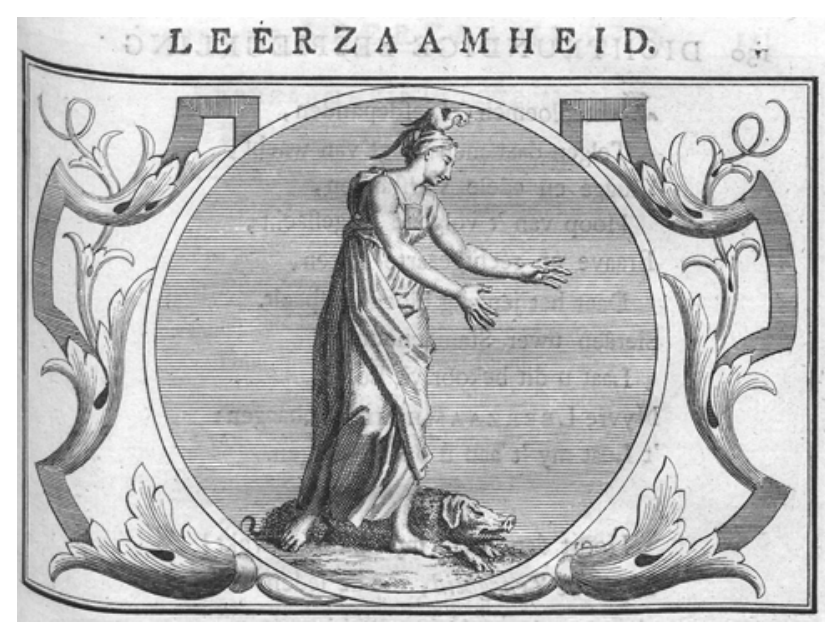

Figure 6. 'Leerzaamheid' in J.P. Broeckhoff, Dicht- en zedekundige zinnebeelden en bespiegelingen [Poetic and edifying emblems and contemplations]. Amsterdam, P.J. Entrop bookseller, 1770, 129. (c) Utrecht University Library.

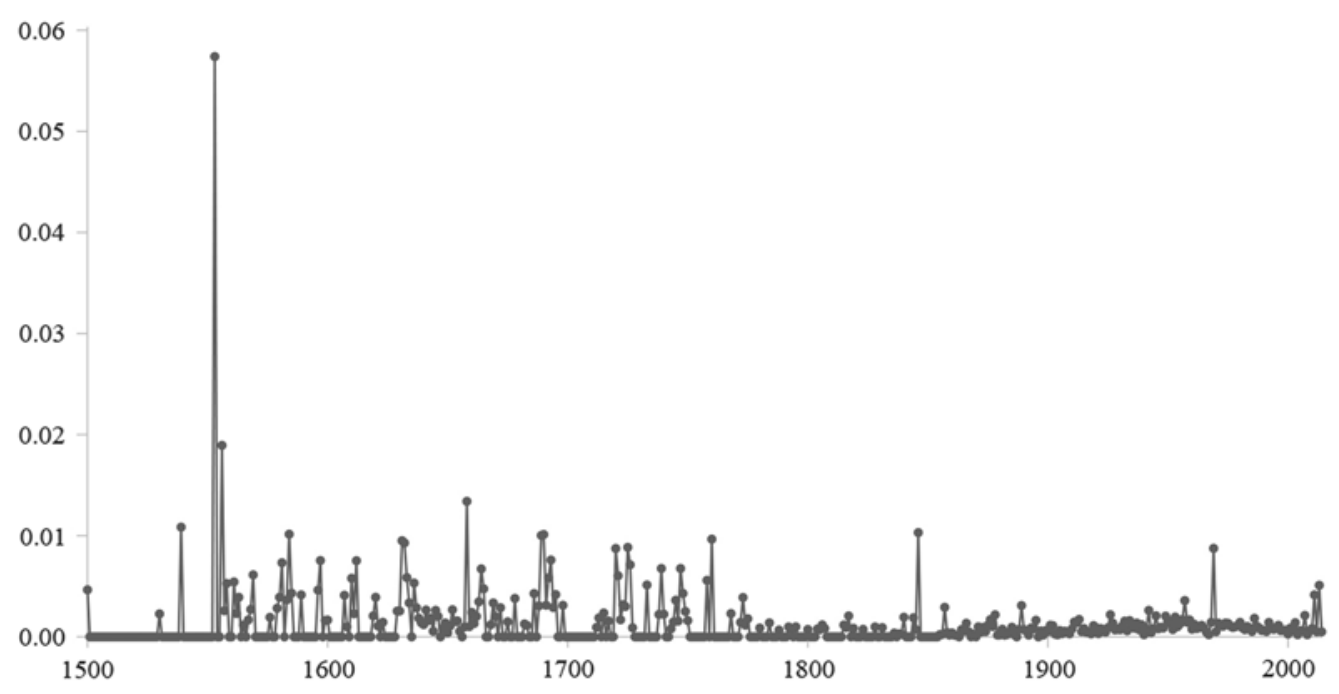

Ngram instellingen

inventie (1729)

Figure 7. Overview produced by the DBNL nGram tool of the frequency and distribution of Dutch word inventie.

has no such connection to youth for it simply reads "una bella donna" (Ripa 1603, 240). The Dutch 1644 edition does include a reference to the youth of this woman: "Een jonge Vrouwe met prachtige kleedinge, in 't wit" [A young woman dressed in exquisite clothes, in white] (Ripa [1644] 1971, 550). Looking at the nGram results of the use of the Dutch word inventie and its spelling variants, it becomes apparent that this word is used frequently in the early modern period, especially between 1550 and1750 (see fig. 7).

A close look at the text in which these words are used reveals that these are - despite the Dutch Ripa's association - not used in relation to youth. The words are used by scholars and travelers 
such as Christiaan Huygens to indicate the discovery of new objects, locations, or phenomena. It is telling that in Cornelis de Bie's Het gulden cabinet van de edel vry schilderconst, references to leergierige en weetgierige youth are frequently made (for instance, De Bie 1662, 66 and 68). On the one occasion, however, that De Bie uses the word inventie, the context is age-neutral: "Daer nochtans alleen de cracht der Consten in verborghen is, dat is de inventie" [The power of the free arts lies in invention] (De Bie 1662, 436). The use of the word inventie thus reinforces the impression that youthful curiosity in the Dutch context is not represented as explorative in nature, but confined to the reproduction of adult knowledge as captured in books.

A brief glance at translations of Cesare Ripa's authoritative Iconologia demonstrates how other European cultures might have sent another message to the young (see fig. 8). The first English translation of Ripa's Iconologia, dating from 1709, depicted curiosity as a negative quality - just as the Italian and Dutch version did:

She has abundance of Ears and Frogs on her Robe; her Hair stands up on end; Wings on her Shoulders; her Arms lifted up; she thrusts out her Head in a prying Posture. The Ears denote the Itch of knowing more than concerns her. The frogs are Emblems of Inquisitiveness, by reason of her google-Eyes. The other things denote her running up and down, to hear, and to see, as some do after News. (Ripa 1709, 5)

On her robe an "abundance of Ears and Frogs" symbolizes "the Itch of knowing more than concerns her"; the frogs in particular are emblems of Inquisitiveness. Her problem is that she wants to hear and see more than appropriate, "as some do after News." No association with learning or knowledge acquisition has been made in the English version. We do, however, see this association - as well as the link to youth - in a series of other lemmata in this English version: the lemmata on "Invention" and "Apprehension" (see fig. 9). "Invention" is also a young person:

Figure 8. "Curiosity" in Iconologia, or, Moral emblems, by Cesare Ripa. (Eds. Pierce Tempest \& Isaac Fuller, London: Benjamin Motte, 1709, 20). (C) Utrecht University Library.

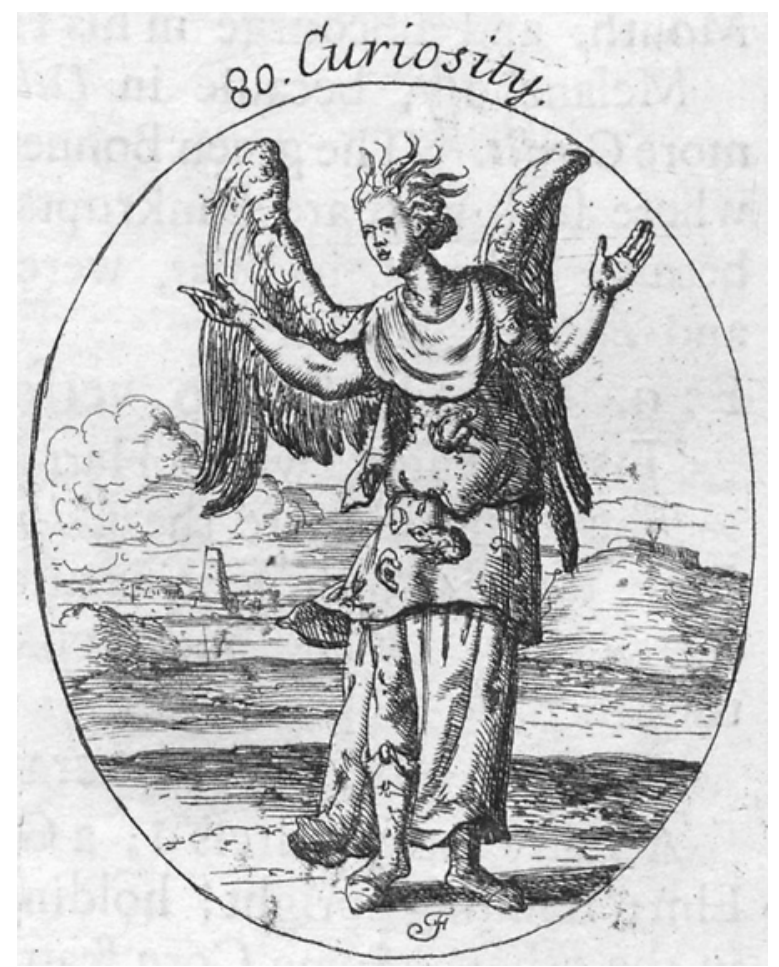




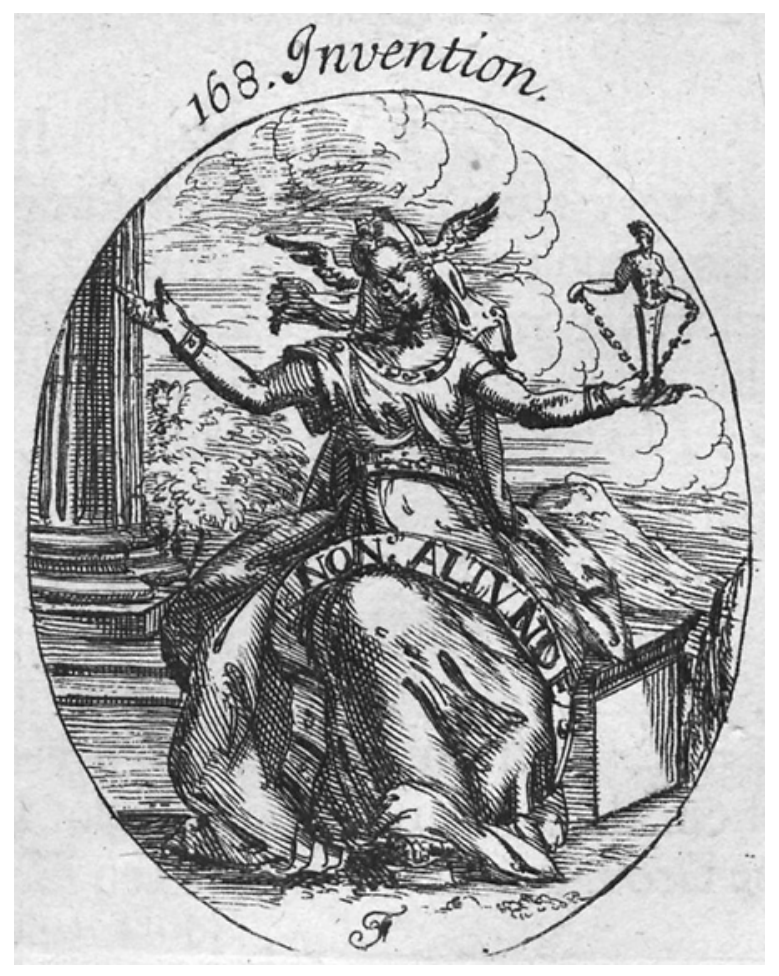

Figure 9. "Invention" in Iconologia, or, Moral emblems, by Cesare Ripa. Eds. Pierce Tempest \& Isaac Fuller, London: Benjamin Motte, 1709, 42. (c) Utrecht University Library.

The Mistress of Arts appears in a white Robe, whereon is written, NON ALIUNDE; two little Wings on her Head; in one Hand, the Image of Nature, a Cuff on the other, with the Motto, AD OPERAM. Youth denotes many Spirits in the Brain, where Invention is form'd; the white Robe, the Pureness of it, not making use of another Mens Labor [sic], as the Motto shews. The Wings, Elevation of Intellect; naked Arms, her being ever in Action, the Life of Invention. The Image of Nature shews her Invention. (Ripa 1709, 42)

Much more details are given than in the Dutch version of Ripa. Invention is formed in a youthful brain, as the texts reads (see fig. 10). The lemma "Apprehension" (Apprehensiva in some Italian versions of Ripa) is equally detailed:

A young Lady of a middle Stature, all in white, brisk and active, dispos'd to listen to another speaking; a Camelion in one Hand, and a Miroir in the other. Youth denotes her Aptness to apprehend and learn, middle Stature, denotes the fame; for the upper Rooms are always worst furnish'd, spoken of a very Tall person; White, because it is the Ground of all Colour; on tiptoe, shews the Readiness she is in to learn and understand; the Glass because she imprints on herself, and makes all the hears and sees her own. (Ripa 1709, 20)

Not only learning, but understanding is now one of her main features. In all, the English version presents a much more detailed and persuasive image of youthful invention and apprehension to the reader than the Dutch textual culture at large. This indicates that perhaps different cultures posited different relationships among curiosity and youth. 
Figure 10. "Apprehention," in Iconologia, or, Moral emblems, by Cesare Ripa. Eds. Pierce Tempest \& Isaac Fuller, London: Benjamin Motte, 1709, 5. (C) Utrecht University Library.

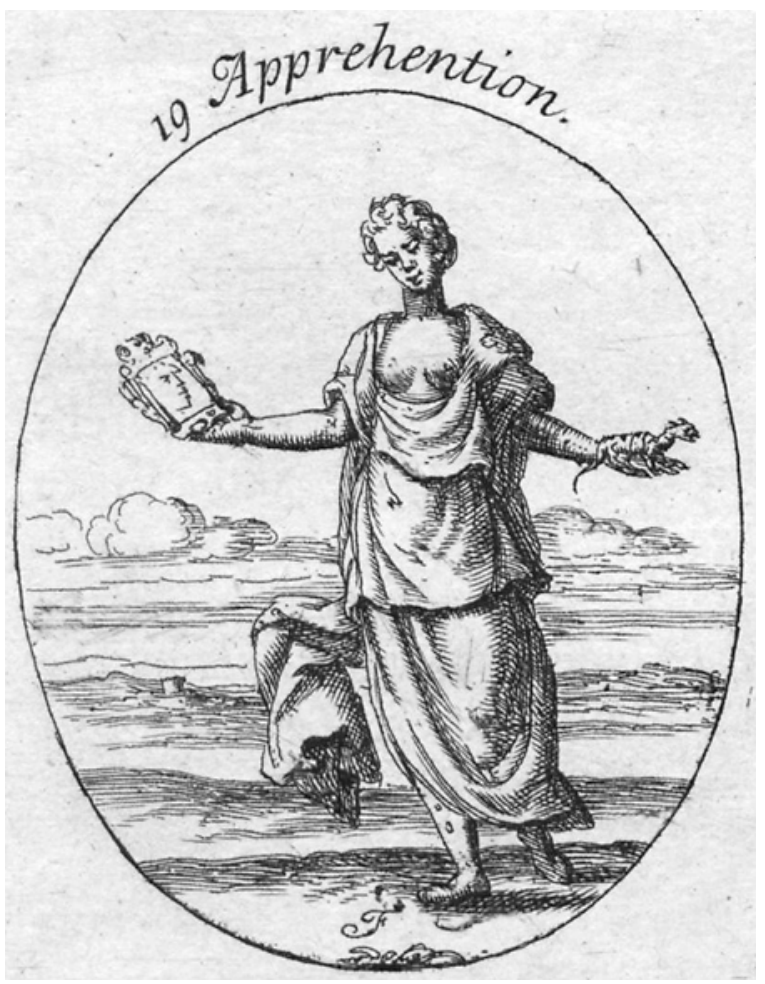

\section{Representation of Learning Styles}

What do we see when we move away from the actual use of the words of members of the "curiosity family" in Dutch textual and visual culture and have a look at representations of the learning styles of young people? This question is sparked by two articles of the Dutch art historian, Jan Baptist Bedaux, who concludes that curiosity was not an inherent element of youthful learning style: Dutch children's portraits and illustrated texts from that period represented children as caged parrots, as trained and tamed dogs, and as bridled horses. Bedaux argues that the metaphors celebrated abstinence from sexual immorality as well as restraint from explorative behavior (Bedaux 1982 and Bedaux 1991). They were most likely known to both adults and their children, for they were used, for instance, in emblem books that were meant to be read by parents and their children together. An emblem discussed by Bedaux and made by Jacob Cats depicts a parrot (see fig. 11); the accompanying poem reads:

Dwanck leert sanck [Discipline teaches speech]

If the parrot would have stayed in the woods, it would have led an uncultivated, wild life. Now that it is domesticated by humans, it learns how to speak, being in such a civilized environment. Whoever wants to achieve great things in life should patiently do whatever is required and what is forced upon him by discipline. Discipline in one's youth, brings nothing but joy in the future. ${ }^{12}$

\footnotetext{
${ }^{12}$ Dutch quotation: 'Indien de Papegay waer in het wout ghebleven,/Sy hadde daer gheleyt een woest en beestigh leven,/ Maer nu sy door bedwangh by menschen is gheleert,/Soo komtet datse spreect, en in het hof verkeert./Is yemant oyt ghesint om eere na te jaghen,/Hy moet van eersten af, hy moet ghewilligh draghen/Al wat de tucht ghebiet. Bedwangh ontrent [=ten tijde van] de jeught/Wort eere metter tijdt, en niet als enckel vreught.' (Cats 1627, 82).
} 


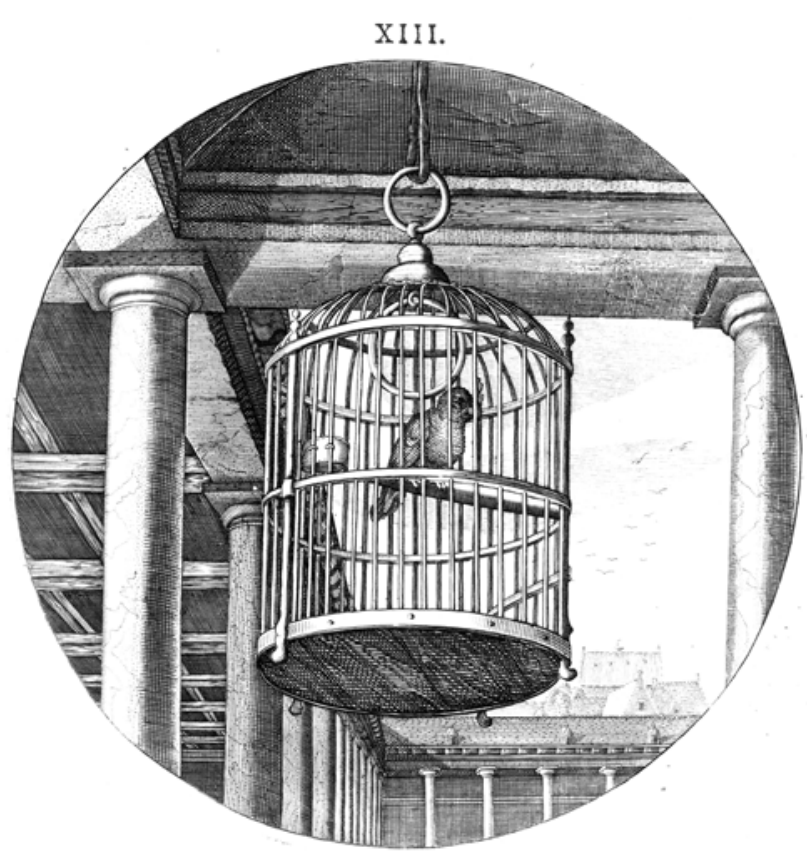

Figure 11. "Dwanck leert sanck," in J. Cats, Sinne-en minnebeelden [Moral and love emblems]. Rotterdam: Pieter van Waesberge, 1627, 80. (c) Utrecht University Library.

These metaphors persistently presented a reminder of the importance of control over one's intellectual development. Discipline rather than curiosity was the idealized principle behind the learning style of the young, as embodied by the parrot.

The frequent use of the metaphor of the parrot signals its importance for early modern pedagogical and educational debates. For instance, Jan Amos Comenius, a Czech philosopher, pedagogue and theologian who was famous across Europe for his attempts to change the early modern school system, made ample use of this metaphor in his Orbis Sensualium Pictus [Visible World in Pictures], 1658. To underline the need to approach the children's learning processes in a different manner, he dismissed the idea that children should be trained like parrots in his preface of "The Translator, to all judicious and industrious School-Masters" (here quoted in an English translation dating from 1705):

Whereas indeed, we generally ... do teach children as we do Parrots, to speak they know not what, nay which is worse, we, taking the way of teaching little ones by Grammar only at the first, do puzzle their imaginations with abstractive terms and secondary intentions, which till they be somewhat acquainted with things, and the words belonging to them, in the Language which they learn, they cannot apprehend what they mean. (Comenius 1705, fol. A6r-v; emphasis in the original)

To Comenius, the educational ideal of memorization was harmful because young children were forced to handle abstract terminology. They would end up using the appropriate terms, but not grasp the true meaning of what they say - and thus resemble a parrot (see fig. 12). Yet, as revolutionary as Comenius was, his educational approach did not imply a complete revision of the school system, nor of the text books used at schools. In the school he depicted in his Orbis Sensualium Pictus, memorization is still an important activity:

Schoolmasters and pupils are depicted at work: "Quidam stant \& recitant memoriae mandata" (Comenius 1679, 360; "Some stand and rehearse things committed to memory," in the English translation of 1705 (Comenius 1705, I4r). Comenius's Orbis Sensualium Pictus was not translated 
Figure 12. "Schola," Johann Amos Comenius, Orbis Sensualium Pictus Quadrilinguis Emendatus, Hoc est: Omnium fundamentalium in mundo Rerum, \& vita Actionum, Pictura \& Nomenclatura, [...]. Nuremberg: Michael Endteri, 1679, 360. (c) Royal Library, The Hague.

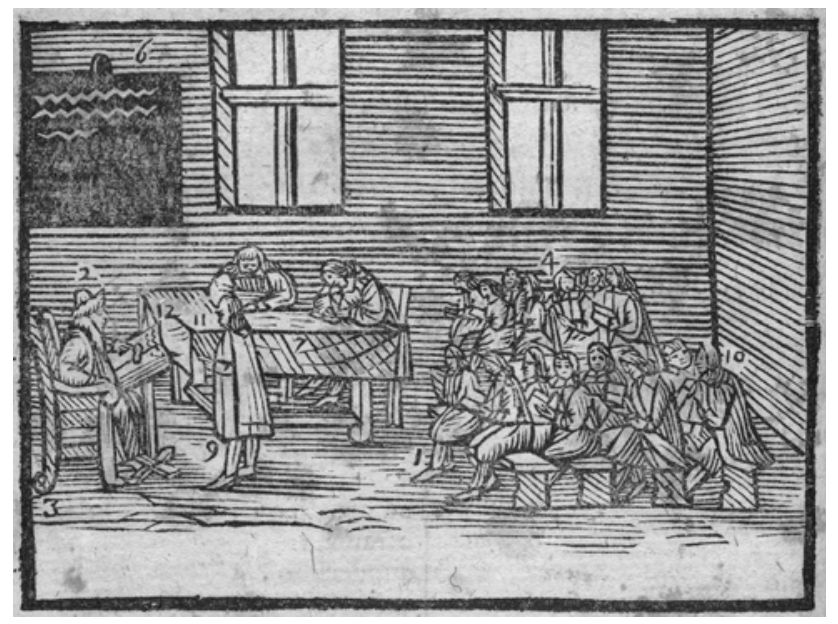

into Dutch or published in the Dutch Republic, and perhaps as a result had limited influence on Dutch discourses during the seventeenth century. Judged by the number of Dutch translations of Comenius' oeuvre printed after 1700 and eighteenth-century educational treatises, his influence on eighteenth-century developments toward an inclusive public school is more obvious (Mercks 1999, 219-220; Lenders 1988). Yet, some of Comenius' work and ideas must have been known even in the seventeenth-century Dutch Republic: some Dutch readers were able to read the Latin versions that circulated in the international trade of Latin books.

In a Dutch edition of another book by Comenius, indeed published in the Dutch Republic itself, in 1658, the dialogue format is suggested as an alternative to memorization:

Everywhere we send out questions first, as if everything were of a dialogical nature. In this way the attention will be more easily focused on the thing at hand, and later repetitions and examinations can be organized. ${ }^{13}$

The questions serve as a cover up: they suggest that learning is done by means of a dialogue, but in reality questions only result in repetition and examination of what is already known among adults. It can be concluded that the imitation of adults remained the dominant educational model in pedagogical treatises such as Comenius' Orbis Sensualium Pictus and seventeenth century school systems (Jacobs 2014 for the English context; Put 1990 for the Dutch context).

Outside these pedagogical discussions in textual discourses, representations of learning styles in pictorial representations are dominated by the ideal of discipline and reproduction; this tendency, already detected by Bedaux in early seventeenth-century emblematic culture, is also present in Dutch song culture and Dutch theatre texts from the late seventeenth and early eighteenth century - as testified by for instance the many reprints and adaptations of the comedy Kluchtigh Avontuurtje van 't Nieuwsgierigh Aeghje van Enckhuysen [Joyful Adventure of the Curious Aagje from Enkhuizen] by Abraham Bormeester (first printed around 1662). The main character's name "nieuwsgierig Aagje" even became proverbial, and acts in modern Dutch as the synonym of unbridled curiosity). ${ }^{14}$ Educational metaphors depicting bridled horses and tamed dogs, to express

\footnotetext{
${ }^{13}$ Latin original: 'Praemittimus ubique interrogationes, ut quasi dialogistica sint Omnia: quia sic facilius attentio in rem praesentem excitatur, \& repetitiones postea, examinaque instituuntur.' (Comenius 1658, fol. ${ }^{\star} 5 \mathrm{v}$ ). Translation provided by Arnoud Q. Visser, and one of the anonymous reviewers.

${ }^{14}$ See for reprints of the comedy the Short Title Catalogue Netherlands (http://stcn.nl); and for adaptations of the play to songs, the Liederenbank (Dutch Songs Database, at http://liederenbank.nl).
} 

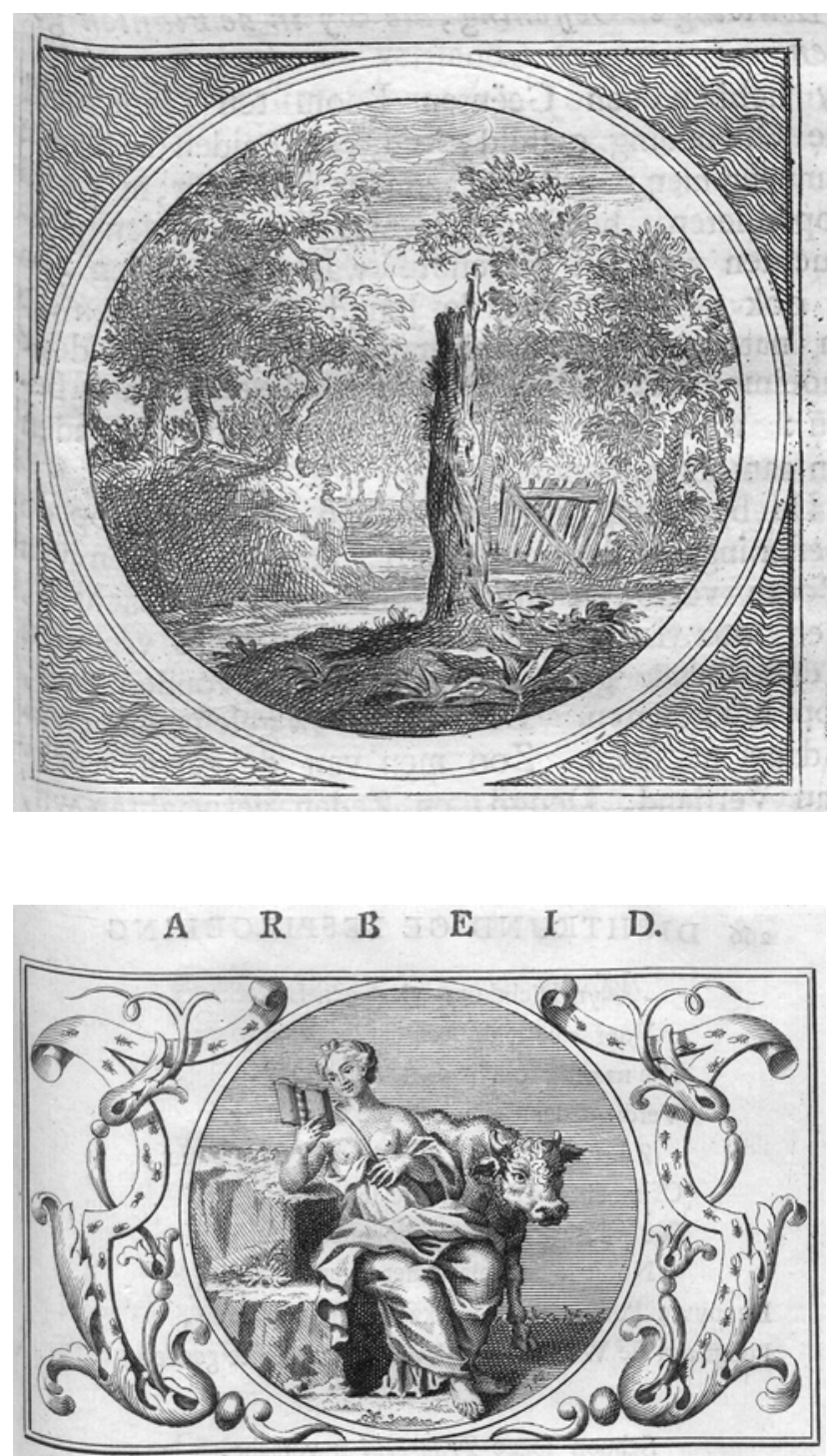

Figure 13. A. Houbraken, Stichtelyke zinnebeelden, gepast op deugden en ondeugden, in LVII tafereelen vertoond door $A$. Houbraken, en verrykt met de bygedichten van Juffrouw Gezine Brit [Edifying emblems, applied to virtues and vices, depicted in 57 images made by A. Houbraken and Enriched with poems by Miss Gezine Brit]. Amsterdam 1767, 119. (c) Utrecht University Library.

Figure 14. J.P. Broeckhoff, Dicht- en zedekundige zinnebeelden en bespiegelingen [Poetic and edifying emblems and contemplations]. Amsterdam, P.J. Entrop, 1770, 265. (c) Utrecht University Library.

the idea that youth's learning process has to do with control and repression, are persistent through the beginning of the eighteenth century (see fig. 13). In Houbraken's Stichtelyke zinnebeelden ([1723] 1767) for instance, young people are represented as trees in need of cultivation and trimming:

Books, the ultimate means to stimulate and guide the inquisitive youth, are not represented as spaces that allow the young minds to wonder (e.g., Feike Dietz in this volume on books that allow and stimulate this type of reading), as we see in these emblems by Broekhoff (see figs. 14 and 15). In these emblems, Labor and Youth show how learning is done: by studying what others have written down in those books that are fully recommended and composed by adults. Reading is thus a controlled and tamed process.

During the eighteenth century, though, more mixed models and ideals arise. The title page of G. de Laraisse's Grondlegginge ter teekenkonst, for instance (see fig. 16), is adorned with a 
Figure 15. J.P. Broeckhoff, Dicht- en zedekundige zinnebeelden en bespiegelingen [Poetic and edifying emblems and contemplations]. Amsterdam, P.J. Entrop, 1770, 361. (c) Utrecht University Library.

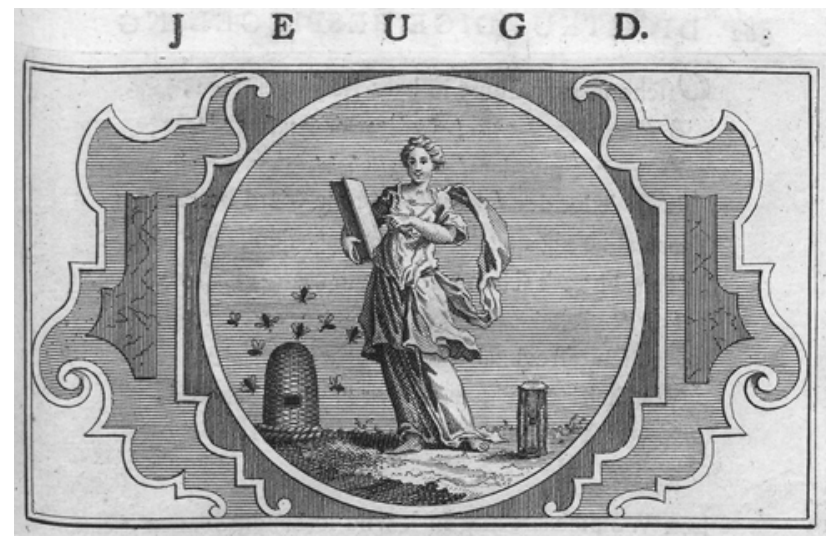

Figure 16. G. de Laraisse, Grondlegginge ter teekenkonst: zynde een korte en zeekere weg om door middel van de geometrie of meetkunde, de teeken-konst volkomen te leeren [Principles of the art of drawing: A short and certain way to master the art of drawing through geometry]. Amsterdam, 1701, fol. *1v. (c) Royal Library, The Hague.

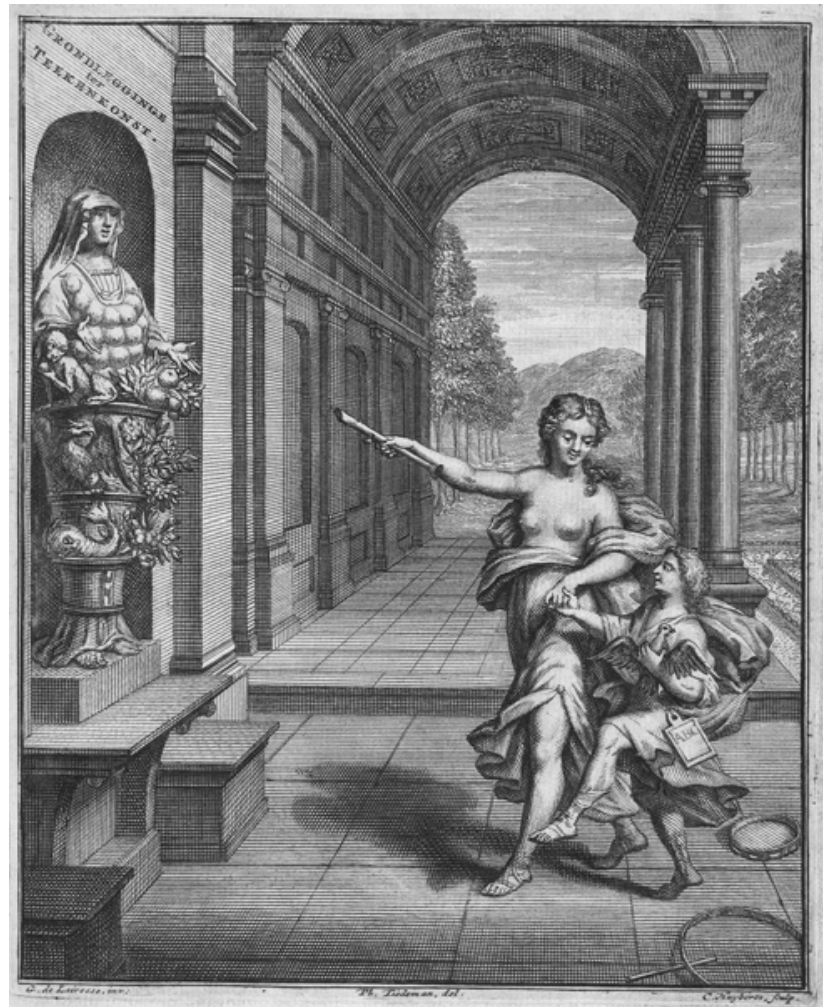

young figure holding a parrot and an ABC-book - symbols of the policy of control and guidance over the youth's learning processes (see also Bedaux 2000 and Bedaux 1982):

But in the two laudatory poems that accompany this title page, another and more empirical view of learning processes is discussed. The first poem, by Cornelis Sweerts, explains how young people's brains must be ready to pick up knowledge. When young people's brains are mature enough, they will make young people long for knowledge:

An adorable child is introduced to mother Nature by the Art of Painting, to enjoy the milk that will sprout from mother Nature's breasts, as soon as Inquisitiveness takes control over 


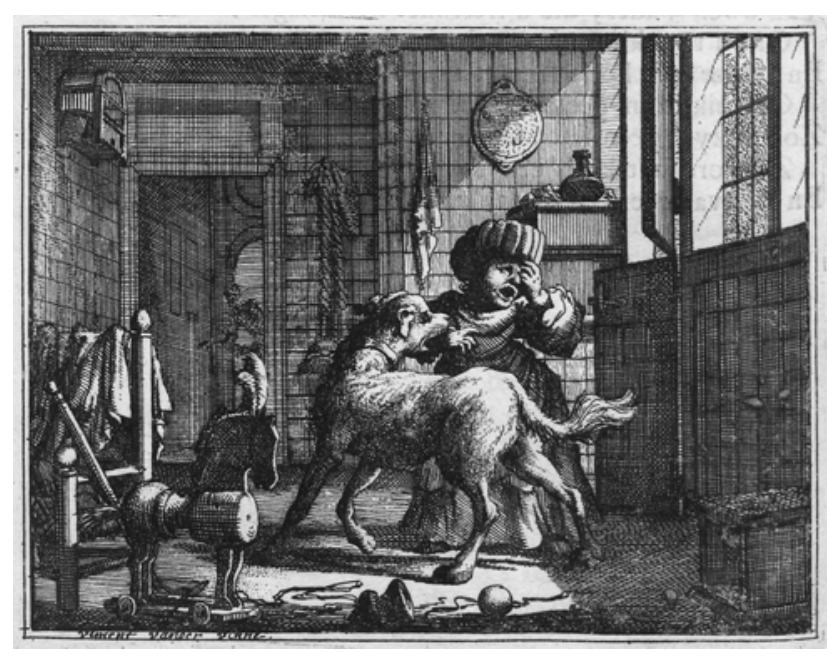

Figure 17. Adriaan Spinniker, Leerzame zinnebeelden [Educational emblems]. Haarlem, 1757, 158-159. (C) Utrecht University Library.

the child's brain and over the brain of whoever is longing for knowledge. This scene shows us with the contest between Nature and Wit. ${ }^{15}$

So while one learns how to paint and create art, one's mind is taken over by inquisitiveness. As a result, a profound interest in the wonders of nature is sparked.

The second poem introduces elements - "al speelend" [while playing] and "na de proef" [experiment] - that emphasize the voluntary nature of learning. Once the motivation to learn is sparked, pupils have only to follow their master's lead:

Humans are born with the seed of science, even though they differ in nature. The force of science is unknown until it sprouts, in one's youth, from one's clever brain. Adults should therefore cherish youngsters, and leave them be. While youngsters have a natural tendency towards the arts, and toward nature that is the perfect teacher of young people with inquisitive hearts. ${ }^{16}$

Nature is represented here as youth's preferred teacher; this entails a plea for more empirical learning processes, not based on the reading of classical and biblical authorities.

In Adriaan Spinniker's Leerzame zinnebeelden we find an even more overt invitation to explore (see fig. 17). Spinniker for instance depicts the young child who learns not to pat a dog if the dog does not want this, as an example for adults (Spinneker 1757, 158). ${ }^{17}$

Just as the young child learns by doing, the adults should learn from the experiences gained during their lives. If they stumble upon vain and empty elements in life, they should avoid them just as the child avoids a grumpy dog.

\footnotetext{
${ }^{15}$ Dutch quotation: 'Op de tytelprent./Hier word een aardig Kind, door Streelgeest, voortgeleid/Tot vrouw Natuur, om 't zog, dat uit driedubb'le borsten/Ontspringen zal, zo dra de Leerzucht zich verspreid/In 't brein der Jonglingschap, en die na'er kennis dorsten./Wy zien, in 't oop'nen van dit heerlyk Konsttooneel, Natuur en Geestigheid ten stryd gaan op "t Paneel.' (De Laraisse 1701 , fol. ${ }^{\star} 2 \mathrm{v}$ ).

${ }^{16}$ Dutch quotation: 'Op de zelve./Het zaad der weetenschap word met de mensch gebooren,/Hoewel niet eens van aart; men kent zyn krachten niet/Voor dat in 't eerst der lent het flaauwe blyken schiet,/Waar uit een schrander brein 't vernuft spelt van te vooren./Dit jeugdig spruitje dient gekoestert na behooren;/Geen forsse dwang baart goed; de geeft lyd geen verdriet/Zy geeft, al speelend, zich aan streelnimphs bly gebied/Die leid haar na de proef wat nutst haar dient verkooren./Natuur toont dubb'le gunst door haare vruchtbaarheid,/Aan jonge Geesten, wien een liefde tot haar leid/Die 't leerziek hart in zucht tot 't hoogst der kunst doet blaaken.' (De Laraisse 1701, fol. ${ }^{\star} 2 \mathrm{v}$ ).

${ }^{17}$ Quoted and shown is the second edition, that is similar to the first edition of 1714 .
} 
Because of specific youthful qualities (such as good eyesight), young people are able to gain the type of knowledge that will stay with them for the rest of their lives (Spinniker [1714] 1757, 8-11). So there is an intrinsic quality to the knowledge of the young that adults should value: "Whoever had perfect eyesight in his youth had the opportunity to learn the names of the various colors and the competence to distinguish them. ${ }^{18}$

The most far-stretching innovation Spinniker introduces is the image of the young traveler as symbol for the inquisitive mindset young people and adults should have. The young traveler conveys the message that life should be looked upon as a journey. The valuable lessons learned during one's travels will lead one to heaven (ibid., 16). Here his advice touches upon the widespread convention "to script the self" in terms of a journey among adults (Pollmann 2017, 1946), and more specifically perhaps on the ideal of the grand tour for Dutch youth (Hendrix 2009). The preface to the Nieuwe reize van Misson na en door Italien explains how young people travel abroad to wonder at what they see: De meeste jonge reizigers gaan 'er na toe, met een voornemen om alles te verwonderen, en in die gedachten dat ze'er een oneindige menigte verbazende dingen zullen zien [Most young people go there to experience and be surprised] (Misson 1724 , fol. $2 \mathrm{v}$ ). The ones that are only interested in the culture shock they will experience, might as well stay home, Misson writes. Only those whose nieuwsgierigheid [curiosity] is sparked by what they see, who want to know more datze wel alle de boeken willen doorlezen, die van steden en plaatzen welke zy bezocht hebben, schrijven [who want to read all books ever written on the cities they visit], should travel abroad (ibid., ${ }^{\star} \mathrm{r}$ ). This is one of the rare cases in which the word nieuwsgierigheid is favored over leerzuchtig, and in which the reading of books is not presented as an obligatory activity but as an act that makes you wiser about the things you want to know (fig. 18) (e.g., see Feike Dietz's contribution in this volume on function and form of travel literature for the youth).

This is also one of the early cases in which an empirical learning style based on curiosity is approved and even actively promoted. In the Almanach voor beminnaars van weetenschappen geleerdheid en goeden smaak [Almanac for the Lovers of Science, Erudition and Good Taste], first printed in 1779 and reprinted in 1781 and 1785, the virtue of "Freedom" is explained (see fig. 19):

Figure 18. Adriaan Spinniker, Leerzame zinnebeelden [Educational emblems]. Haarlem, 1757, 14. @ Utrecht University Library.

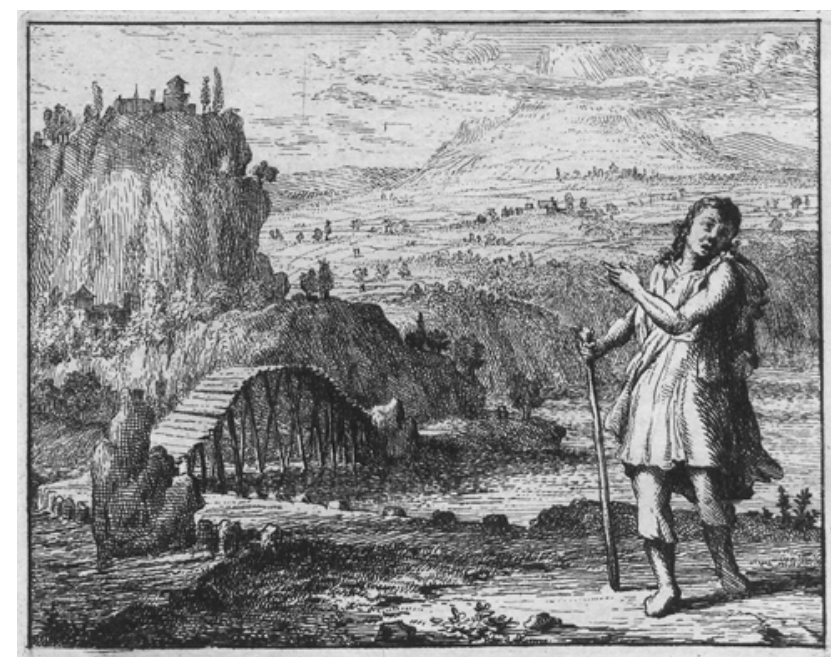

\footnotetext{
${ }^{18}$ Dutch quotation: 'Die in zyn' jongen jeugd den kostelyken schat/Van klaar gezicht bezat,/Kon tot de kennis van den naam der verwen raken,/En keurig onderscheid van de eene en de and're maaken:' (Spinneker 1757, 8).
} 


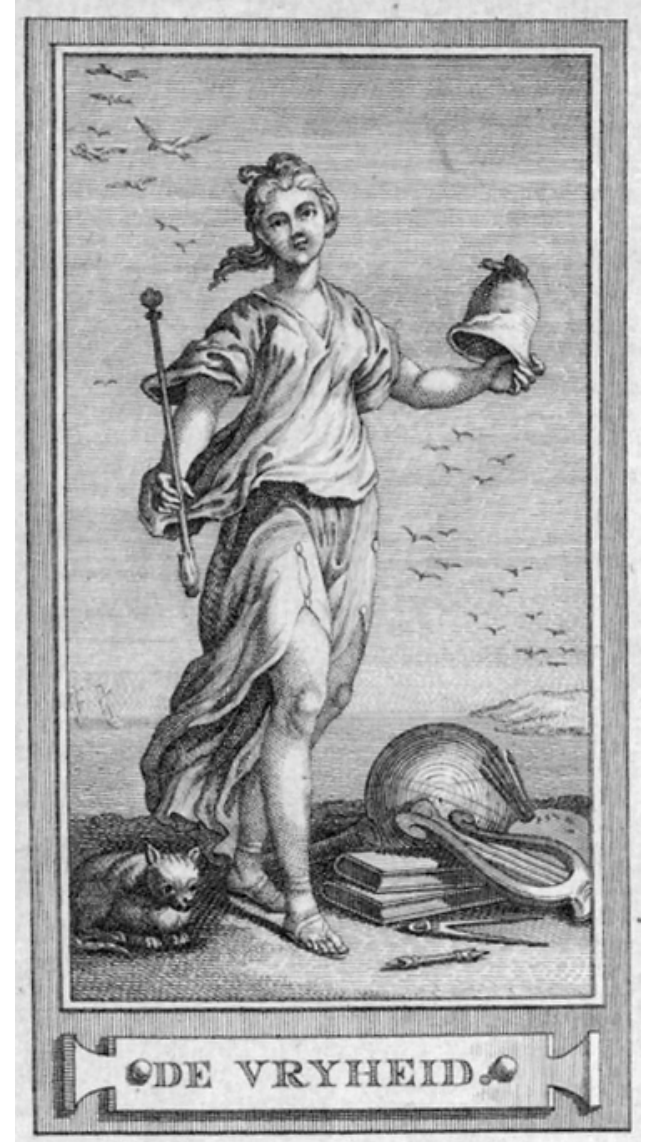

Figure 19. Almanach voor beminnaars van weetenschappen geleerdheid en goeden smaak. Amsteldam, A.E. Munnikhuisen, [1785], 13. (c) Amsterdam University Library.

At her feet is a cat, "vyandin van allen dwang" [enemy of all forms of control]. Freedom itself is a young girl, not an adult woman as many of the other allegories in this almanac. The 'Vrije kunsten' are Freedom's domain, which implies she also controls science (as depicted in the books beside her) (Almanach voor beminnaars van weetenschappen geleerdheid en goeden smaak 1785, 13).

\section{Conclusion}

As we have seen, in the Dutch Republic, curiosity was mostly articulated in representations of forms of Inquisitiveness. "Inquisitiveness," youth, and "knowledge from books" proved to be a powerful and long-lasting combination. Not only the more quantitative analyses made with the nGram viewer, but also the more in-depth linguistic analyses, point out that youthful explorative behaviour was restricted to reading along the lines of books written by adults. Gaining knowledge rather than gaining experience was the main message of literary texts such as emblem books, songs, and plays up to the late eighteenth century. Dutch literary texts actively promoted the traditional learning style of memorization and mirroring as youth's best behavior in this period. Even more so, as a little peek in English translations of Ripa's authorative Iconologia seems to suggest, than literary texts in some other European countries at the time. Young people's behaviour was thus modelled after a passive rather than active manner of acquiring knowledge, in the realm of literature.

I also found proof of changes: from the beginning of the eighteenth century onwards, literary texts that were made especially for adults encouraged their adult readers to follow the example of 
empirical learning found in young children and to use that learning to their benefit. Rather than control and tame the youth, adults were invited to experiment and learn from the experiential model of learning young people presented, even before young people themselves were inspired to do so in children's literature for literary texts for children with young protagonists driven by curiosity, or with emblematic young travellers on their journey in life, mostly date from the second half of the eighteenth century. Existing research has pointed out that at the same time, shifts occurred in pedagogical discourses in the Dutch Republic. The intellectual elite initiated a change in the Dutch educational system, in an attempt to include the working class in this system. Part of their efforts were directed toward the production of lower cost text books used in schools. Additional research into this rising genre is needed to establish if representations of curiosity were incorporated in these text books, and if so, what message these representations convey. From a pilot study I conducted into text books on the Dutch language (in which language is presented as an object of empirical study for Dutch youth), I am inclined to maintain that these text books were not as invariable as often stated (see for instance Buijnsters and Buijnsters-De Smet 1999) and are also indicative of a larger shift in the cultural paradigm of "curiosity."19

\section{References}

Bedaux, Jan B. 1982. "Beelden van "leersucht" en tucht: Opvoedingsmetaforen in de Nederlandse schilderkunst van de zeventiende eeuw [Images of inquisitiveness and discipline. Educational Metaphors in the Visual Arts of the Seventeenth Century]." Nederlandsch Kunsthistorisch Jaarboek 33:49-74.

Bedaux, Jan B. 1991. “'A Bridle for Lust:' Representations of Sexual Morality in Dutch Children's Portraits of the Seventeenth Century." In From Sappho to De Sade (Routledge Revivals): Moments in the History of Sexuality, edited by Jan N. Bremmer, 60-68. London: Routledge.

Bedaux, Jan B. 2000. “Inleiding [Introduction]." In Kinderen op hun mooist: Het kinderportret in de Nederlanden 1500-1700 [Children at their most beautiful: Portraits of children in the Low Countries 1500-1700], edited by Jan B. Bedaux and Rudi Ekkart, 11-32. Gent -Amsterdam: Ludion.

Benedict, Barbara. 2001. Curiosity: A Cultural History of Early Modern Inquiry. Chicago: University of Chicago Press.

Blair, Ann. 2016. "Noël-Antoine Pluche as a Jansenist natural theologian." Intellectual History Review 26:91-99.

Brown, Penny. 2009. “"Girls Aloud”; Dialogue as a Pedagogical Tool in Eighteenth-Century French Children's Literature.” The Lion and the Unicorn 33:202-218.

Buijnsters, Piet. 1995. "Traditie en vernieuwing: Nederlandse ABC-boeken uit de achttiende eeuw [Tradition and renewal: Dutch ABC books from the Eighteenth Century]." In A is een Aapje: Opstellen over ABC-boeken van de vijftiende eeuw tot heden [A is for Ape: Essays on ABC books from the fifteenth century till today], edited by Jaap ter Linden, Anne de Vries and Dick Welsink, 55-72. Amsterdam: Em. Querido's Uitgeverij.

Buijnsters, Piet, and Buijnsters-Smets, Leontine. 1999. Bibliografie van Nederlandse school- en kinderboeken 1700-1800 [Bibliography of Dutch school books and children's literature]. Zwolle: Waanders.

Christensen, Nina. 2009. "Lust for Reading and Thirst for Knowledge: Fictive Letters in a Danish Children's Magazine of 1770." The Lion and the Unicorn 33:189-201.

Cohen, Floris. 2010. How Modern Science Came into the World: Four Civilizations, One 17th-Century Breakthrough. Amsterdam: Amsterdam University Press.

Collier, David, Fernando David Hildalgo, and Andra Olivia Maciuceanu. 2006. "Essentially Contested Concepts: Debates and Applications." Journal of Political Ideologies 11:211-246.

Dorren, Gabrielle Maria Elisabeth. 2001. Eenheid en verscheidenheid: De burgers van Haarlem in de Gouden Eeuw [Unity and diversity: The citizens of Haarlem during the Golden Age]. Amsterdam: Prometheus/Bert Bakker.

Eijnatten, Joris Van, Jaap Verheul, and Toine Pieters. 2014. “TS Tools: Using Texcavator to Map Public Discourse." Tijdschrift voor Tijdschriftstudies 35:59-65.

Evans, Robert \& Alexander Marr, eds. 2004. Curiosity and Wonder from the Renaissance to the Enlightenment. Aldershot: Ashgate.

Fornäs, Johan. 1995. "Youth, Culture and Modernity." In Youth Culture in Late Modernity, edited by Johan Fornäs and Göran Bolin, 1-12. London: Sage Publications.

Frijhoff, Willem, and Marijke Spies. 2004. Dutch Culture in a European Perspective: 1650, Hard-Won Unity. Assen: Van Gorcum. Frijhoff, Willem. 2012. "Historian's Discovery of Childhood." Paedagogica Historica 48: 11-29.

Gallie, Walter Bryce. 1956. “Essentially Contested Concepts.” Proceedings of the Aristotelian Society 56:167-198.

\footnotetext{
${ }^{19}$ To be published as "Language as an Object of Empirical Study for Dutch Youth", to be published in Knowing Objects. Volume 2 in the Series: Creating a Knowledge Society in a Globalizing World (Routledge, 2019).
} 
Grootes, Eddy. 1987. "Het jeugdig publiek van de "nieuwe liedboeken" in het eerste kwart van de zeventiende eeuw [The young consumer of the 'New Song Books' in the first quarter of the Seventeenth Century]." In Het woord aan de lezer: Zeven literatuurhistorische verkenningen [Giving word to the reader: Seven literary historical explorations], edited by Wim van den Berg and Johanna Stouten, 72-88. Groningen: Wolters Noordhoff.

Harrison, Robert Pogue. 2014. Juvenescence: A Cultural History of Our Age. Chicago: University of Chicago Press.

Hendrix, Harald A. 2009. "From Early Modern to Romantic Literary Tourism: A Diachronical Perspective." In Literary Tourism and Nineteenth-Century Culture, edited by Nicola J. Watson, 13-24. Basingstoke: Palgrave Macmillan.

Houston, Rab. 2002. Literacy in Early Modern Europe. London: Routledge.

Houswitschka, Christoph. 2006. "Locke's Education or Rousseau's Freedom.” In Fashioning Childhood in the Eighteenth Century: Age and Identity, edited by Anja Müller, 81-91. Aldershot: Ashgate.

Huff, Toby E. 2011. Intellectual Curiosity and the Scientific Revolution: A Global Perspective. Cambridge: Cambridge University Press.

Jacobs, Gabriel. 2005. "Hypermedia and Discovery Based Learning: What Value?." Australian Journal of Educational Technology 21:355-366.

Jacobs, Margaret. 2014. The First Knowledge Economy: Human Capital and the European Economy, 1750-1850. Cambridge: Cambridge University Press.

Jochum, Klaus Peter. 2006. “Defoe’s Children.” In Fashioning Childhood in the Eighteenth Century: Age and Identity, edited by Anja Müller, 157-167. Aldershot: Ashgate.

Jorink, Eric. 1999. Wetenschap en wereldbeeld in de Gouden Eeuw [Science and the view on the world during the Golden Age]. Hilversum: Verloren.

Kenny, Neil. 2004. The Uses of Curiosity in Early Modern France and Germany, Oxford and New York: Oxford University Press.

Koepp, Cynthia. 2006. "Curiosity, Science and Experiential Learning in the Eighteenth Century: Reading the Spectacle de la Nature." In Childhood and Children's Books in Early Modern Europe 1550-1800, edited by Andrea Immel and Michael Witmore, 153-180. New York: Routledge.

Koselleck, Reinhart. 2006. Begriffsgeschichten. Frankfurt am Main: Suhrkamp.

Koops, Willem. 2001. "Historical Reframing of Childhood." In The Wiley-Blackwell Handbook of Social Development, edited by Peter K. Smith \& Craig H. Hart, 82-89. New York: Wiley-Blackwell.

Koops, Willem. 2016. Een beeld van een kind: De ontwikkeling en opvoeding van het kind in historisch perspectief [The image of a child: The development and upbringing of children in historical perspective]. Amsterdam: Boom.

Langereis, Sandra. 2014. De woordenaar: Christoffel Plantijn, 's werelds grootste drukker en uitgever (1520-1589) [The master of words: Christoffel Plantin, the greatest printer and publisher (1520-1589)] Amsterdam: Boom.

Lenders, Jan. 1988. De burger en de volksschool: Culturele en mentale achtergronden van een onderwijshervorming [The citizen and the public school: Culture and mentality of an educational reform]. Nederland 1780-1950. Nijmegen: SUN.

Mercks, Kees. 1999. "Het beeld van de Tjechische literatuur in Nederland [The image of Czech literature in the Netherlands].' In Brünner Beiträge zur Germanistik und Nordistik Series 4: 217-226.

Müller, Anja, ed. 2006. Fashioning Childhood in the Eighteenth Century: Age and Identity, Aldershot: Ashgate.

Müller, Anja, ed. 2009. Framing Childhood in Eighteenth-century English Periodicals and Prints, 1689-1789. Aldershot: Ashgate.

Neiman, Susan. 2014. Why Grow Up? Subversive Thoughts for an Infantile Age. London: Macmillan Publishers.

Neve, Otto De. 1963. "Aantekeningen over 16de-eeuwse lexicografie [Notes on sixteenth-century lexicography]." Tijdschrift voor Nederlandse Taal- en Letterkunde 79:200-210.

Newhauser, Richard. 2013. "Curiosity". In The Oxford Guide to the Historical Reception of Augustine, edited by Karla Pollmann and others, vol. 2, 849-851. Oxford: Oxford University Press.

Pollmann, Judith. 2017. Memory in Early Modern Europe, 1500-1800. Oxford: Oxford University Press.

Put, Eddy. 1990. De cleijne schoolen: Het volksonderwijs in het hertogdom Brabant tussen Katholieke Reformatie en Verlichting (eind 16de eeuw-1795) [Small schools: Primary education for the unprivileged in the duchy Brabant between reformation and enlightenment (end of the sixteenth century-1795)]. Leuven: Universitaire Pers Leuven.

Salman, Jeroen. 2001. "Children's Books as a Commodity: The Rise of a New Literary Subsystem in the Eighteenth-Century Dutch Republic.” Poetics 28:399-421.

Stronks, Els. 2015. Invisible Ink: Uncovering Meaning from Texts with Digital Tools. Uhlenbeck lectures. Wassenaar: NIAS.

Strauss, Gerald. 1978. Luther's House of Learning: Indoctrination of the Young in the German Reformation. Baltimore: Johns Hopkins University Press.

Walsham, Alexandra. 2011. "The Reformation of the Generations: Youth, Age and Religious Change in England 1500-1700." Transactions of the Royal Historical Society, 6th series, 21: 93-12.

Zimmermann, Hans-Joachim. 1995. "English Translations and Adaptations of Cesare Ripa's Iconologia: From the 17th to the 19th Century.” De Zeventiende Eeuw 11:17-25. 


\section{Primary Sources}

Bie, Cornelis De. 1662. Het gulden cabinet van de edel vry schilderconst [The golden cabinet of the honourable art of painting]. Antwerpen: Jan Meyssens, Juliaen van Montfort.

Broeckhoff, Johan Pieter. 1770. Dicht- en zedekundige zinnebeelden en bespiegelingen [Poetic and edifying emblems and contemplations] Amsterdam: P.J. Entrop.

Cats, Jacob. 1627. Sinne- en minnebeelden [Moral and love emblems] Rotterdam: Pieter van Waesberge.

Cats, Jacob. 1862. [1655]. Alle de werken [Complete works], edited by Jan van Vloten. Zwolle: De Erven J.J. Tijl.

Comenius, Joh. Amos. 1658. Eerste deel der school-geleertheyd, genoemt Het portael. = Prima pars scholasticae eruditionis, dicta Vestibulum [The first part of the school learning, or the portal]. Amsterdam: G. de Roy.

Comenius, Joh. Amos. 1679. Orbis Sensualium Pictus Quadrilinguis Emendatus, Hoc est: Omnium fundamentalium in mundo Rerum, \& vita Actionum, Pictura \& Nomenclatura, [...]. Noribergæ: Michaelis \& Joh. Friderici Endterorum.

Comenius, Joh. Amos. 1705. Joh. Amos Commenii Orbis Sensualium Pictus: hoc est, omnium principalium in mundo rerum, et in vita actionum, pictura et nomenclatura = Joh. Amos Commenius's Visible World: or, a nomenclature, and pictures of all the chief things that are in the world, and of mens employments therein; in above an 150 copper cuts. Written by the author in Latin and High-Dutch being one of his last essays, and the most suitable to childrens capacities of any that he hath hitherto made. Translated into English by Charles Hoole. For the use of young Latin scholars. London: John Sprint.

Den Nederduytschen Helicon [The Dutch Helicon]. 1610. Alkmaar: Jacob de Meester.

Houbraken, Arnold. 1767 [1723]. Stichtelyke zinnebeelden, gepast op deugden en ondeugden, in LVII tafereelen vertoond door A. Houbraken, en verrykt met de bygedichten van Juffrouw Gezine Brit [Edifying emblems, applied to virtues and vices, depicted in 57 images made by A. Houbraken and Enriched with poems by Miss Gezine Brit]. Amsterdam: Willem Barents.

Laraisse, Gerard De. 1701. Grondlegginge ter teekenkonst: zynde een korte en zeekere weg om door middel van de geometrie of meetkunde, de teeken-konst volkomen te leeren [Principles of the art of drawing: A short and certain way to master the art of painting through geometry]. Amsterdam: Willem de Coup.

Misson, Maximilian. 1724. Nieuwe reize van Misson na en door Italien: met een berecht voor de gene die voornemens zyn dezelve reize te doen: vermeerdert en opgeheldert met de Aanmerkingen van Addisson, door hem gemaakt gedurende zyne reize door Italien: vit het frans na den vyfden druk vertaelt en met schoone kopere platen versiert [New journey of mission to and through Italy: With an instruction for those planning the same trip: Enlarged and clarified with notes by Addision (as made during his trip through Italy]. Utrecht: Willem van de Water.

Ripa, Cesare. 1603. Iconologia, ouero, Descrittione di diuerse imagini cauate dall'antichità, \& di propria inuentione. Rome: Lepido Facius.

Ripa, Cesare. 1625. La Novissima Iconologia del sign. cavalier Cesare Ripa. Padova: Pietro Paolo Tossi, 1625.

Ripa, Cesare. [1644] 1971. Cesare Ripa's Iconologia of Uytbeeldinghen des Verstants, vertaald door Dirck Pietersz. Pers [Cesare Ripa's Iconologia or depiction of wisdom, translated by Dirck Pietersz. Pers]. edited by Jochen Becker. Soest: Davaco Publishers.

Ripa, Cesare. 1709. Iconologia, or, Moral emblems, by Cesare Ripa. London: Benjamin Motte.

Spinniker, Adriaan. [1714] 1757. Leerzame zinnebeelden [Educational emblems]. Haarlem: Jan Bosch.

Els Stronks is Professor of Early Modern Dutch Literature and Culture at Utrecht University. She previously taught at Indiana University in Bloomington, Indiana. She is the author of several books on early modern Dutch visual and literary culture and has written a number of articles on the technical approaches used in a number of digitization projects that she participates in. She is currently involved in the research project Golden Agents that aims to unravel the dynamics of the Dutch Republic's creative industries digitally; in this project, her focus is on the young producers and consumers of books.

Cite this article: Stronks, Els. 2019. "Curiosity, youth, and knowledge in the visual and textual culture of the Dutch Republic," Science in Context 32:213-236. doi:10.1017/S0269889719000152 